\title{
Concrete precast rejects - treatment, characterization, and application in new concrete as recycled aggregate
}

\section{Rejeitos de pré-fabricados de concreto - tratamento, caracterização e aplicação em novos concretos como agregado reciclado}

\author{
Victor M. E. Lima ${ }^{1 *}$, Stela Fucale ${ }^{2}$, Amanda M. Estolano ${ }^{1}$, Romildo A. Berenguer ${ }^{1}$, Nathan B. \\ Lima $^{1}$, Larissa C. Cabral ${ }^{1}$, Heliana C. Nascimento ${ }^{1}$, Nathalia B. D. Lima ${ }^{1}$.
}

\begin{abstract}
This article evaluates the feasibility of using concrete waste from precast production as recycled aggregate in concrete. The processing of concrete waste employed a jaw-hammer crusher and a sieve, producing three types of Recycled Concrete Aggregate (RCA). After their characterization, RCA was incorporated in two types of concrete used in the precast factory: a flowing concrete (FC), slump $220 \mathrm{~mm}$, employed in columns and beams; and the second one, a no-slump extruded concrete (NSC), used for hollow core slabs. X-Ray diffraction, thermogravimetric analysis and scanning electronic microscopy showed phases from the hydrated cement paste and the original aggregate. Results of mechanical performance showed that RCA did not influence the compressive strength but influenced other properties such as water absorption and modulus of elasticity. Lastly, it was concluded that RCA obtained in the precast factory showed great potential to be used within the factory production process.
\end{abstract}

Keywords: Recycled concrete aggregate; Compressive strength; Modulus of elasticity; Rebound hardness.

\section{RESUMO}

Este artigo avalia a viabilidade do uso de resíduos de concreto da produção de pré-moldados como agregado reciclado no concreto. O processamento dos resíduos de concreto empregou um britador de mandíbula e uma peneira, produzindo três tipos de Agregado de Concreto Reciclado (RCA). Após sua caracterização, o RCA foi incorporado em dois tipos de concreto utilizados na fábrica de pré-moldados: um concreto fluido (FC), abatimento $220 \mathrm{~mm}$, empregado em pilares e vigas; e o segundo, um concreto extrudado sem abatimento (NSC), utilizado para lajes alveolares. A difração de raios-X, a análise termogravimétrica e a microscopia eletrônica de varredura mostraram fases da pasta de cimento hidratada e do agregado original. Os resultados do desempenho mecânico mostraram que o RCA não influenciou a resistência à compressão, mas influenciou outras propriedades, como absorção de água e módulo de elasticidade. Por fim, concluiuse que o RCA obtido na fábrica de pré-moldados apresenta grande potencial para ser utilizado no processo produtivo da fábrica.

Palavras-chave: Agregado reciclado de concreto; Resistência à compressão; Módulo de elasticidade; Esclerometria

\footnotetext{
${ }^{1}$ Universidade Federal de Pernambuco, Recife, Brasil *E-mail: victor.estolano@ufpe.br

${ }^{2}$ Escola Politécnica de Pernambuco, Universidade de Pernambuco, Recife, Brasil.
} 


\section{INTRODUCTION}

The use of recycled aggregates (RA) from construction waste brings environmental and social benefits to society. One of the direct benefits is to prevent this type of waste to be deposited in illegal areas, which tend to affect mostly the poorest of the population. In addition to the known benefits, the demand for RA research is increasing for several reasons, such as: (1) the growth of the world population, which raise the demand for construction materials; (2) the scarcity of natural aggregates around the world (MENDES, 2012; MUKHARJEE; BARAI, 2014; World Business Council for Sustainable Developmen, 2009); (3) lack of areas for legal disposals, such as landfills (TAFFESE, 2018).

Therefore, a feasible solution to this issue is to reuse these wastes again in applications such as aggregate or filler for cement and concrete. In some countries of Europe (SALESA et al., 2017; SOARES et al., 2014), RA has been used in structural concrete, replacing natural aggregate, and, in 2018, RA represented only $8 \%$ of the total amount of aggregates produced in the EU (UEPG, 2018). This occurs due to the existence of standardization and the scarcity of natural resources, which is likely to happen soon in most countries of the world. Thus, research with recycled aggregates from different sources of waste such as construction and demolition, precast concrete, bricks, granite, marble, agroindustry ash, among other types aimed to make feasible the incorporation of these wastes in mortar and concrete. Although the use of recycled aggregate still seems small in Europe, it is relevant when compared to other regions such as South America, which has no surveys on this subject. Several factors justify resistance to the use of RA, which is explained by some authors (ISMAIL; HOE; RAMLI, 2013; SILVA, R. V.; DE BRITO; DHIR, 2014).

Particularly in Brazil, there is no standardization for regulating the use of recycled aggregate in structural concrete. Because of the plenty of mineral resources in the country, the construction business has not given due importance to this issue in recent decades. However, this scenario has been changing owing to the scarcity of aggregate reported in 
important urban centers, such as São Paulo and Curitiba (MENDES, 2012). In the case of the Northeast region, it was reported that the rocks along the Borborema Plateau have a high potential to develop the alkali-silica reaction (PRADO, 2008), and that it was a potential source of obtaining aggregates until then. Therefore, the use of recycled aggregate is a issue that has been gaining importance in Brazil in recent years.

The origin of the waste directly interferes with the properties of the recycled aggregate. Recycled concrete aggregate (RCA) is a class of RA originating from concrete waste, which is obtained from concrete producing and concrete precast rejects. The recycling in concrete plants has a tremendous advantage when compared to a purchase of RA from an external recycling plant, due to the elimination of the purchase and freight charges. Yet, when compared to natural aggregate (NA), RCA presents lower density (up to 10\%)(ARORA; SINGH, 2016; MARINKOVIC et al., 2012; YANG; CHUNG; ASHOUR, 2008), greater capacity to absorb water (DE BRITO PRADO VIEIRA; DOMINGUES DE FIGUEIREDO; JOHN, 2020; RAO; JHA; MISRA, 2007; SILVA, R. V.; DE BRITO; DHIR, 2014; XIAO; LI; ZHANG, 2005; YANG; CHUNG; ASHOUR, 2008), and lower resistance to wear (OMARY; GHORBEL; WARDEH, 2016; SALESA et al., 2017). This is mainly due to the high porosity of the attached mortar (JAYASURIYA et al., 2021; SOARES et al., 2014), which decreases the quality of RCA and also influences the crushing process and the size of the particles produced. Consequently, these characteristics are transferred to the concrete matrix, resulting in concrete with high porosity (WANG; YU; LI, 2020). Some authors reported an improvement in the mechanical properties of concrete after removing the attached mortar from RAC (SARAVANAKUMAR; ABHIRAM; MANOJ, 2016; SHI et al., 2016).

With respect to the fresh state of concrete with RCA, many researchers have reported a decrease in workability as the amount of RCA increases (KHATIB, 2005; RAO; JHA; MISRA, 2007). These authors concluded that the irregular shape and high porosity of RCA particles lead to an increase in the water amount, considering the workability kept. However, other researchers had different conclusions. Galvín et al. (GALVÍN et al., 2014) reported that the incorporation of coarse RCA did not decrease the value of the slump test. Güneysi et al. (GÜNEYISI et al., 2016) verified an increase on flowability with the increase of fine RCA amount in self-consolidating concrete. Soares et al. (SOARES et al., 2014) concluded that RCA did not lead the water/cement ratio to vary, at the slump range. 
In general, RCA amount affects the mechanical properties of concrete. It is a consensus that the use of RCA in concrete increases its porosity and decreases its modulus of elasticity (CABRAL et al., 2010; DE BRITO et al., 2016; EVANGELISTA; DE BRITO, 2007; KHATIB, 2005; SALESA et al., 2017; SANTOS; DA SILVA; DE BRITO, 2017; SILVA, RUI VASCO; DE BRITO; DHIR, 2016; YANG; CHUNG; ASHOUR, 2008). However, the same does not occur with compressive strength. Many authors have found that the incorporation of RCA results in a decrease of compressive strength as the amount of RCA increases(ARORA; SINGH, 2016; CABRAL et al., 2010; POON; KOU; LAM, 2007). On the other hand, an increase in the compressive strength of concrete with RCA is reported by Domingo-Cabo et al. (2009) and Salesa et al. (2017). In addition to the works cited above, it can be found studies in which no clear trend of increase or decrease is shown when the amount of RCA increases(EVANGELISTA; DE BRITO, 2007; PÉREZ-BENEDICTO et al., 2012; SOARES et al., 2014). Through an extensive literature survey, Jayasuriya et al. (2021) concluded that the incorporation of $20 \%$ recycled aggregate can lead to an increase in compressive strength.

Thus, this paper aims to evaluate the technical feasibility of the employment of RCA from precast rejects as aggregate in concrete mixes used in a precast factory. Due to the inconsistencies found in the literature regarding the influence of RCA on compressive strength, a protocol of statistical analysis was used to interpret the results. This is one of the papers that are part of research on the influence of the use of recycled concrete aggregate for precast manufacturing. Another paper (ESTOLANO et al., 2018) was published focusing on the analysis of the relationship between the modulus of elasticity and the compressive strength.

We hope our findings will encourage the construction technical society to create standardization allowing the use of recycled aggregate in structural concrete, especially in developing countries like Brazil. Besides, this paper will help the construction business to know the characteristics of the recycled aggregate and evaluate how it can be used safely in structural concrete.

\section{MATERIALS}

RCA with different sizes were produced from a concrete precast plant located in the Suape Port Complex (Cabo de Santo Agostinho, Brazil). This plant had three sites of 
waste generation: the line production, where it was generated waste by the leftover concrete, and the faulty concrete pieces, which were rejected by the quality control staff; and the concrete lab, where the waste was generated by crushing the specimens and the rejected mixes in the fresh state assessment. RCA used in this research came from crushed precast elements of strength classes of 35 up to $45 \mathrm{MPa}$, corresponding to prestressed hollow core slabs, produced by the process of extruding dry concrete, as well as prestressed columns and beams and centrifuged piles. It was not possible to evaluate the influence of RCA by the type of concrete, because waste was not sorted. Part of the waste was used as a landfill to expand the factory space, however not enough to avoid the accumulation in piles (Figure 1). Destining the waste to controlled landfills was not a viable solution due to the high cost demanded. During the research period, it was estimated that approximately $49 \mathrm{~m}^{3}$ of waste was generated per month and a total of more than $800 \mathrm{~m}^{3}$ of accumulated waste. This waste had been acumulated for 5 years.

Figure 1 - Piles of concrete waste acumulated in the precast plant.

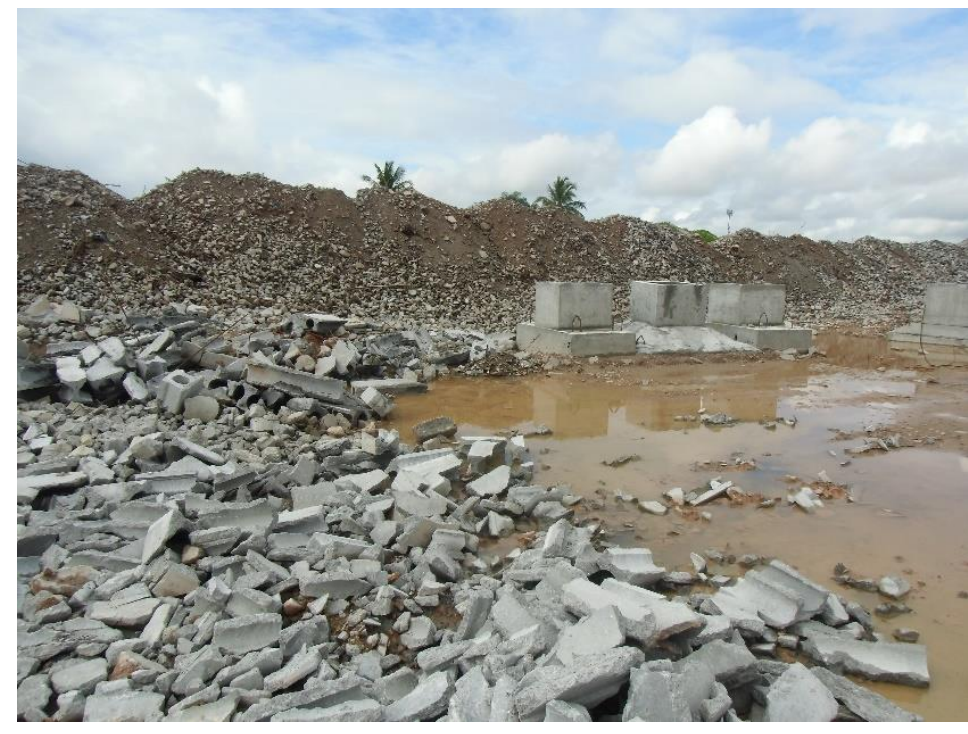

Source: authors' authorship (2021)

The crushing process used to obtain the RA consisted of a jaw-hammer crusher. Two different fractions of RA have been originated from the crushing of the precast concrete elements: a powder-like material named in this study as recycled fine sand (RFS) and one other, which resembled as gravel and named R6.3, according to their maximum diameter size. However, R6.3 corresponded to about $70 \%$ of all material produced. Therefore, to use R6.3 as a fine aggregate, a sample of it was sieved through a $4.8 \mathrm{~mm}$ 
mesh sieve, and the through fraction was named R4.8. Figure 2 shows the recycling process used in the experimental program.

Figure 2 - Recycling process for obtaining RCA samples.

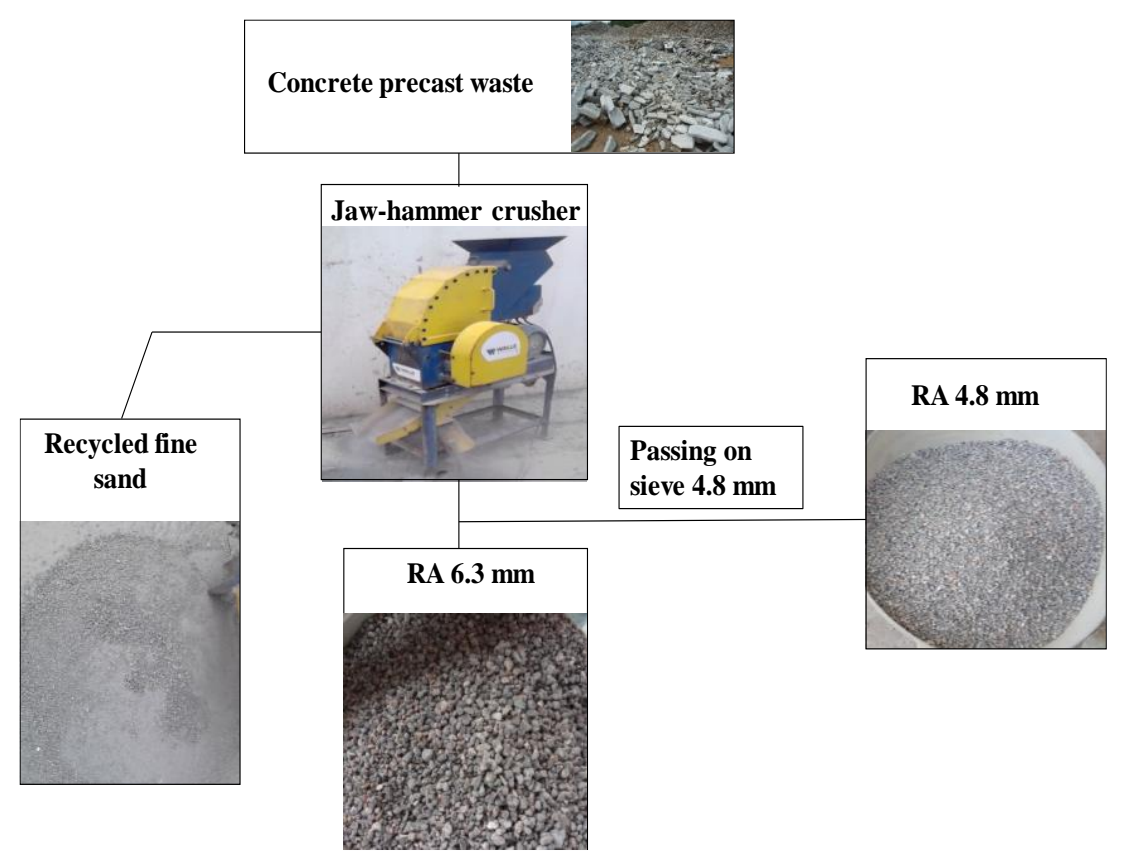

Source: authors' authorship (2021)

The natural aggregates used in the factory were fine quartz sand (FS), with maximum size (MS) of $2.4 \mathrm{~mm}$, and two types of gravel, with MS of $12.5 \mathrm{~mm}$ (G12) and $19 \mathrm{~mm}$ (G19), both from gneiss rock. The results of the aggregates characterization and size distribution tests are presented in Table 1 and Figure 3, respectively, which were performed according to Brazilian standards.

The cement used to produce concrete was a CP-V ARI (high initial strength cement Portland), commonly used for precast concrete plants, and a polycarboxylatebased superplasticizer was MC Bauchemie brand, with the specification PowerFlow 1180. The water was supplied by the Pernambuco Water Supply and Sanitation Company (COMPESA).

Figure 3 - Aggregates' size distributions 


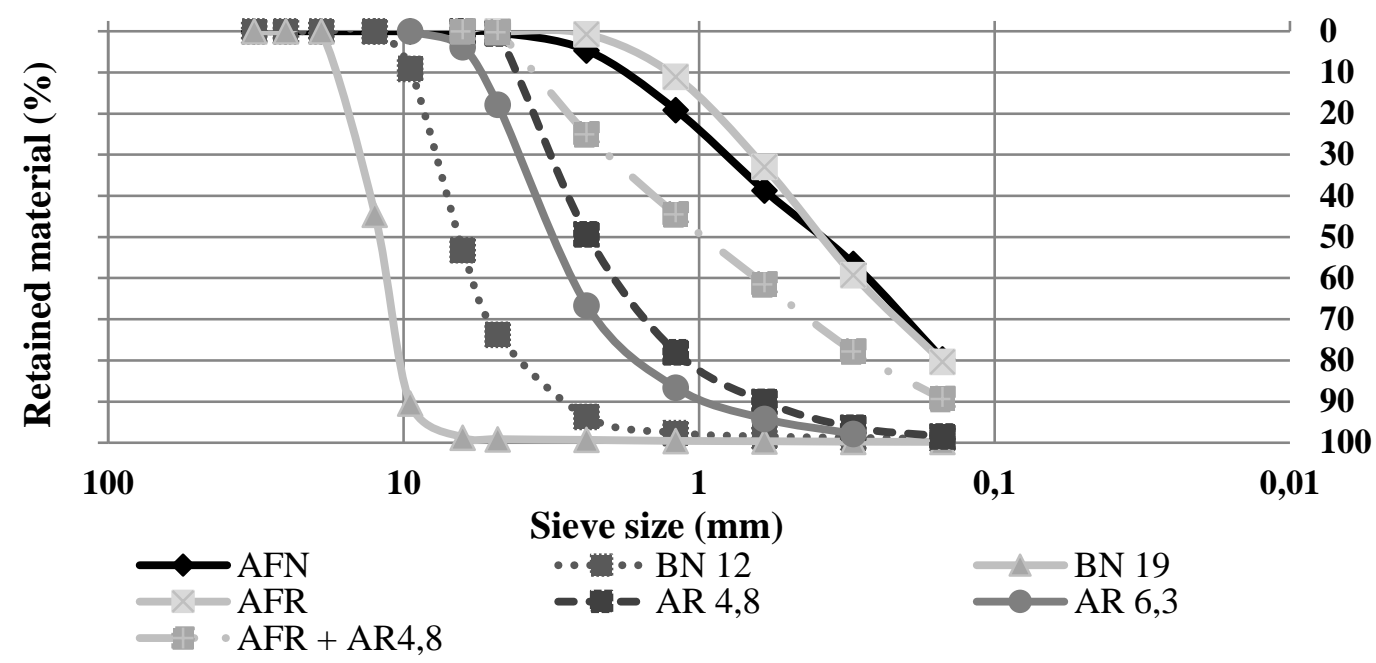

Source: authors' authorship (2021)

Table 1 - Aggregates' characterization

\begin{tabular}{|c|c|c|c|c|c|c|c|}
\hline \multirow{2}{*}{ Test } & \multirow{2}{*}{ Standard } & \multicolumn{3}{|c|}{ Natural aggregate } & \multicolumn{3}{|c|}{ Recycled aggregate } \\
\hline & & FS & G12 & G19 & RFS & RG4.8 & RG6.3 \\
\hline Maximum diameter (mm) & \multirow{2}{*}{ NBR NM 248 (ABNT, 2003) } & 2.4 & 12.5 & 19.0 & 2.4 & 4.8 & 6.3 \\
\hline Fineness modulus & & 1.99 & 6.24 & 8.27 & 1.84 & 4.12 & 4.66 \\
\hline $\begin{array}{l}\text { Water absorption (\%)- } \\
24 \mathrm{~h}\end{array}$ & $\begin{array}{l}\text { NBR NM } 30 \text { (ABNT, 2001) } \\
\text { NBR NM 53:2009 }\end{array}$ & 0.53 & 1.12 & 0.72 & 12.65 & 7.58 & 7.55 \\
\hline \multicolumn{8}{|l|}{ Particles density $\left(\mathrm{kg} / \mathrm{m}^{3}\right)$} \\
\hline Apparent & NBR NM 52:2009 - FA & 2640 & 2720 & 2730 & 2550 & 2540 & 2520 \\
\hline Oven dried & NBR NM 53:2009 - CA & 2510 & 2590 & 2600 & 2100 & 1970 & 1980 \\
\hline Saturated surface dry & & 2540 & 2610 & 2620 & 2360 & 2390 & 2440 \\
\hline Bulk Density $\left(\mathrm{kg} / \mathrm{m}^{3}\right)$ & NBR NM 45:2006 & 1600 & 1370 & 1420 & 1280 & 1350 & 1370 \\
\hline Powder material $(\%)$ & NBR NM 46:2003 & 4.05 & 0.72 & 0.46 & 8.50 & 5.83 & 5.91 \\
\hline Los Angeles wear (\%) & NBR NM 51:2001 & - & 20.48 & 26.49 & - & - & 25.67 \\
\hline
\end{tabular}

\section{METHODS}


Besides the standardized tests, a microstructural assessment was conducted on RAC. The X-ray diffraction (XRD) technique revealed its mineralogical composition. The parameters were set at $\mathrm{i}=10 \mathrm{~mA}, \mathrm{U}=30 \mathrm{kV}$, angular step $=0.02^{\circ}$, scan speed $=5.1^{\circ} / \mathrm{min}$, goniometer speed $=15 \mathrm{rpm}$ and range $=5-80^{\circ}$, using a Bruker D2 Phaser diffractometer. Thermogravimetric (TG) and differential scanning calorimetry (DSC) analysis were performed through a Netzsch STA 449F3 instrument. For both tests, temperature range was 25 to $1000^{\circ} \mathrm{C}$ with a nitrogen flow rate at $50 \mathrm{ml} \cdot \mathrm{min}^{-1}$.

Further those tests, RAC was assessed through optical (OM) and scanning electronic (SEM) microscopy. Also, energy dispersive spectroscopy (EDS) was employed with SEM to identify the chemical compounds in determined phases. OM was performed using an Olympus BX51 microscope (lens magnification: 5x) and the software AnalySIS imager. The SEM/EDS was carried out utilizing a TESCAN MIRA3 electronic microscope, equipped with a tungsten filament operated an accelerating voltage of $10 \mathrm{kV}$, with a working distance of $40 \mathrm{~mm}$. EDS point analysis was acquired through a OXFORD (X-Maxn) detector.

The concrete mixtures chosen for the experimental program have been based on the procedures from the precast concrete plant. Two concrete mixes were used: a flowing concrete (FC), which was used in the manufacture of beams and columns, and a no-slump concrete (NSC), that was used in hollow core slabs made by extrusion. The control concrete FC-control and NSC-control followed the characteristics below:

- FC: target strength $35 \mathrm{MPa}$ (1 day) and $45 \mathrm{MPa}$ (28 days), cement content 485 $\mathrm{kg} / \mathrm{m}^{3}$, type of cement CP-V ARI (a type of high early strength cement), w/c ratio 0.36, mortar contents $(\alpha)$ 0.54, slump $230 \pm 20 \mathrm{~mm}$, and superplasticizer (MC Bauchemie PowerFlow 1180) 0.6\% of cement content (in mass);

- $\quad$ NSC: target strength $25 \mathrm{MPa}$ (1 day) and $35 \mathrm{MPa}$ (28 days), cement content 367 $\mathrm{kg} / \mathrm{m}^{3}$, type of cement CP-V ARI, w/c ratio 0.39 , mortar content $(\alpha) 0.53$, slump zero, SP (MC BauchemiePowerFlow 1180.) 0.4\% of cement content (in mass).

Before the production of control and recycled concrete mixes, some tests have been performed to define the content of the replacement of recycled aggregates, which 
would be used to evaluate the mechanical performance of the mixes. Due to the high absorption of RFS, it was concluded that in mixtures with RA it would be unfeasible to keep a water/cement ratio close to the reference mixture (FC-ref). Therefore, the solution adopted was to decrease the specific surface of the fine aggregate, adopting the composition of $50 \%$ RFS $+50 \%$ AR4.8 for the M1 mixtures.

Then, it was decided to analyze the replacement ratios (in mass) of fine natural aggregate (FS) by fine recycled aggregate (50\% RFS and 50\% RG4.8) in 30\%, 50\%, and $100 \%$. The mixes with $30 \%$ and $50 \%$ reached a slump of $230 \pm 20 \mathrm{~mm}$, according to the established by FC-ref, while with $100 \%$ replacement ratio of recycled aggregates showed a total lack of workability (slump values close to zero), Figure 4. It was not worth adding water to attempt to reach the desired consistency, because such a large increase in the water/cement ratio would lead to a great decrease in the recycled concrete strength. An attempt to improve the workability of the concrete was by adding a superplasticizer content greater than $1.0 \%$. However, the concrete mixture showed a high viscosity, making its use unfeasible. It occurred because the FC-control mixture contained the optimum content of superplasticizer, therefore exceeding the amount of $0.6 \%$, which led to an effect contrary to the desired one.

Figure 4 - FC mixture with $100 \%$ of fine RCA.

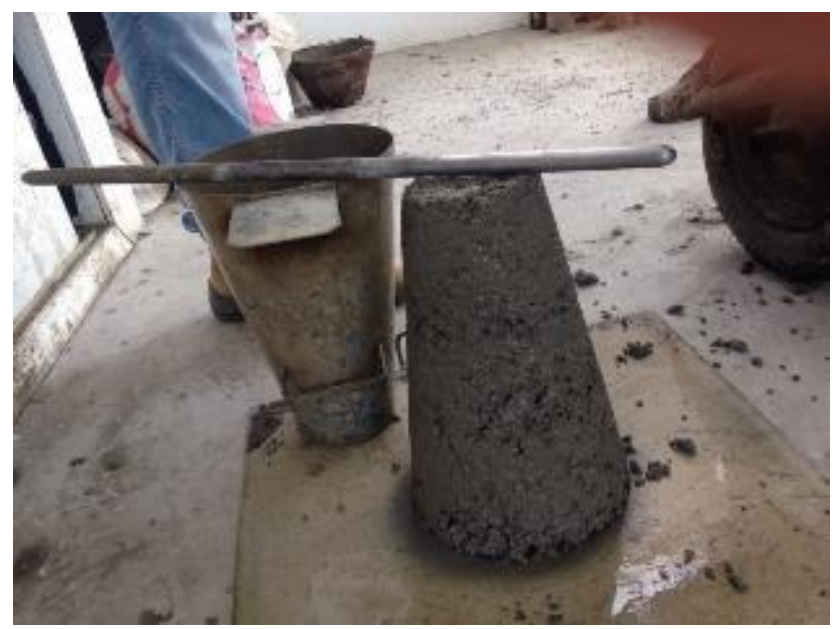

Source: author's authorship (2021)

Concerning NSC, besides the control mixture, a mix with $100 \%$ recycled aggregate (NSC-100) was produced. The replacements carried out in NSC-100 were natural gravel (G12 and G19) with RG 6.3, and NFS with RFS. The compaction of FC mixes was performed applying 12 strokes in each of 2 layers by a metal bar. On the other 
hand, compaction of NSC mixes employed a vibro-pressing desk, compacting the dry concrete in 3 layers. This method simulated the charges of the extrusion machine. Table 2 shows the concrete mixes' composition.

Table 2 - Concretes mixes composition

\begin{tabular}{llllll}
\hline Components & $\begin{array}{l}\text { FC- } \\
\text { control }\end{array}$ & FC-30 & FC-50 & $\begin{array}{l}\text { NSC- } \\
\text { control }\end{array}$ & NSC-100 \\
\hline Cement $\left(\mathrm{kg} / \mathrm{m}^{3}\right)$ & 486.1 & 473.4 & 451.8 & 367.2 & 324.1 \\
FS $\left(\mathrm{kg} / \mathrm{m}^{3}\right)$ & 967.6 & 629.8 & 447.8 & 1028.2 & - \\
G12 $\left(\mathrm{kg} / \mathrm{m}^{3}\right)$ & 288.0 & 279.9 & 267.1 & 932.7 & - \\
G19 $\left(\mathrm{kg} / \mathrm{m}^{3}\right)$ & 529.9 & 516.6 & 493.0 & - & - \\
RFS $\left(\mathrm{kg} / \mathrm{m}^{3}\right)$ & - & 142.0 & 225.9 & - & 907.4 \\
RG4.8 $\left(\mathrm{kg} / \mathrm{m}^{3}\right)$ & - & 142.0 & 225.9 & - & - \\
RG6.3 $\left(\mathrm{kg} / \mathrm{m}^{3}\right)$ & - & - & - & - & 823.1 \\
w/c ratio & 0.36 & 0.36 & 0.37 & 0.40 & 0.45 \\
Water $/ \mathrm{dry}$ materials $(\%)$ & 7.71 & 7.84 & 7.86 & 6.25 & 7.12 \\
\hline
\end{tabular}

In the fresh state, the consistency (slump test) and the fresh density of the concrete mixtures were studied. The slump test followed the procedures of the Brazilian standard NBR NM 67 (ABNT, 1998)

For the evaluation of hardened properties, cylinder specimens with $10 \mathrm{~mm}$ diameter and $20 \mathrm{~mm}$ height were cast. Table 4 shows the tests performed, their respective standards, and the number of replicates for each test. Compressive strength, modulus of elasticity, and splitting tensile strength tests allowed understanding the influence of the use of RAC on the mechanical behavior of the concrete. In the modulus of elasticity test, micro-strain gages were used to measure the strain of the specimens during the load (Figure 5).

Figure 5 - Modulus of elasticity test 


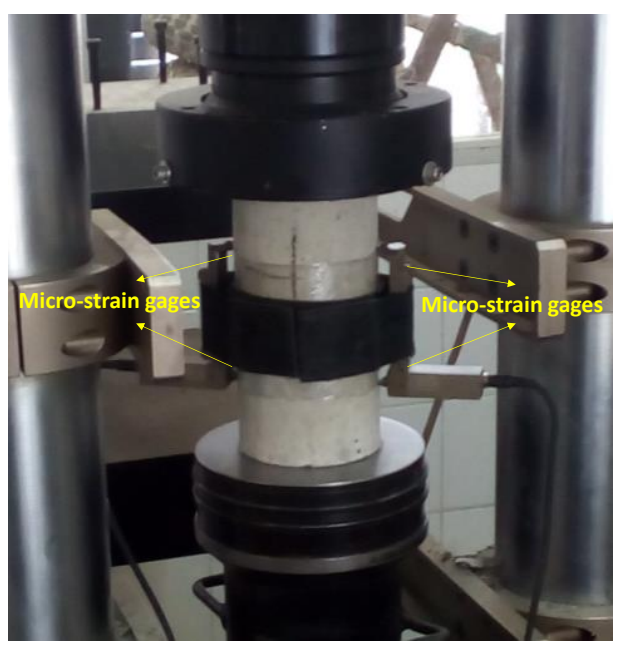

Source: author's authorship (2021)

The values of the dynamic modulus of elasticity $\left(E_{d}\right)$ (Eq. 1) were obtained from the ultrasonic wave velocity $(V)$, the density of the concrete $(\rho)$, and the Poisson's ratio $(\mu)$, which was set at 0.20 .

$$
E_{d}=\rho \times V^{2} \times \frac{(1+\mu) \times(1-2 \mu)}{(1-\mu)}
$$

Water absorption and hardened density allowed a better understanding of the effect of RAC on concrete porosity. To evaluate the surface hardness of the specimens, a Schmidt rebound hammer was used to apply strokes in 16 points on the side of the specimen (Figure 6). In addition to assessing the surface hardness of the materials, it was also studied whether the rebound hammer, applied in concrete specimens, could be an alternative for destructive tests such as compressive strength. To guarantee the stability of the specimens during the application of the stroke, they were loaded to a compression of $5 \mathrm{tf}$. 
Figure 6 - The surface hardness test run (left) and the points of application of the hammer rebound (right).

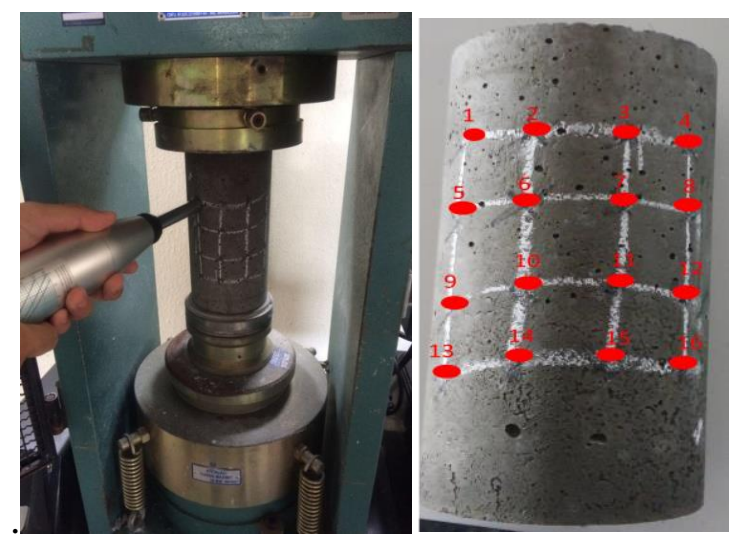

Source: authors' authorship (2021)

Table 3 - Hardened state tests and number of specimens used in the experimental program.

\begin{tabular}{|c|c|c|c|c|c|c|c|}
\hline \multirow[b]{2}{*}{ Test } & \multirow[b]{2}{*}{ Standard } & \multirow[b]{2}{*}{$\begin{array}{l}\text { Age } \\
\text { (days) }\end{array}$} & \multicolumn{5}{|c|}{ Number of specimens (for each age) } \\
\hline & & & $\begin{array}{l}\text { FC- } \\
\text { control }\end{array}$ & $\begin{array}{l}\text { FC- } \\
\mathbf{3 0}\end{array}$ & $\begin{array}{l}\text { FC- } \\
50\end{array}$ & $\begin{array}{l}\text { NSC- } \\
\text { control }\end{array}$ & $\begin{array}{l}\text { NSC- } \\
100\end{array}$ \\
\hline Compressive strength & $\begin{array}{l}\text { NBR } 5739 \\
\text { (ABNT, 2007) }\end{array}$ & $\begin{array}{l}1,7,28, \\
\text { and } 105\end{array}$ & 18 & 18 & 18 & 8 & 8 \\
\hline $\begin{array}{l}\text { Water absorption, } \\
\text { void index, and } \\
\text { density }\end{array}$ & $\begin{array}{l}\text { NBR 9778 } \\
\text { (ABNT, 2009) }\end{array}$ & 105 & 8 & 8 & 8 & 6 & 6 \\
\hline $\begin{array}{l}\text { Dynamic modulus of } \\
\text { elasticity }\end{array}$ & $\begin{array}{l}\text { C } 597 \text { (ASTM, } \\
\text { 2016) }\end{array}$ & 105 & 18 & 18 & 18 & 8 & 8 \\
\hline Rebound hardness & $\begin{array}{l}\text { NBR 7584 } \\
\text { (ABNT, 2012) }\end{array}$ & $\begin{array}{l}1,7 \text {, and } \\
28\end{array}$ & 18 & 18 & 18 & 8 & 8 \\
\hline $\begin{array}{l}\text { Static modulus of } \\
\text { elasticity }\end{array}$ & $\begin{array}{l}\text { NBR 8522 } \\
\text { (ABNT, 2017) }\end{array}$ & 105 & 3 & 3 & 3 & 3 & 3 \\
\hline $\begin{array}{l}\text { Splitting tensile } \\
\text { strength }\end{array}$ & $\begin{array}{l}\text { NBR 7222 } \\
\text { (ABNT, 2011) }\end{array}$ & 105 & 3 & 3 & 3 & 2 & 2 \\
\hline
\end{tabular}

\section{STATISTICAL ANALYSIS}

The minimum number of eight replicates in the compressive strength tests allowed the use of statistical tools to verify if the samples had significant statistical differences. Initially, it was checked if the samples fit the normal distribution. After that, as each one had less than 30 elements, the Student's $\mathrm{T}$ distribution was used, like the normal distribution for the statistical inferences. Finally, the statistical similarity between the 
samples was analyzed by means of the T-tests for means and the normal analysis of variance (ANOVA). Figure 7 shows a flowchart of the protocol adopted for the statistical analysis.

Figure 7 - Flowchart of the protocol used for the statistical analysis.

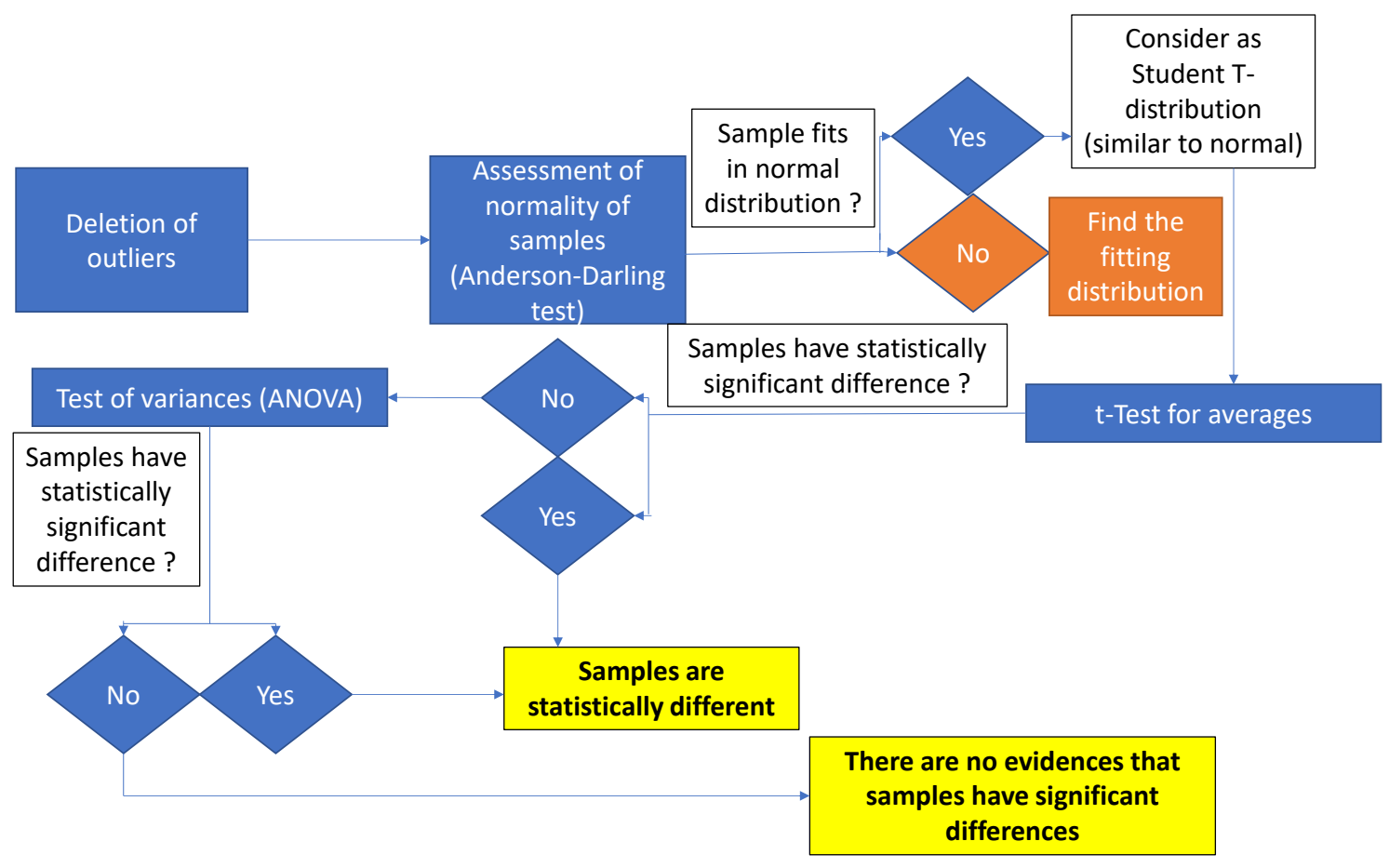

Source: authors' authorship (2021)

\section{RESULTS AND DISCUSSION}

\section{Aggregate's characterization}

Regarding the mineralogical composition, Figure 8 presents the diffractogram of the RCA. The legend of the symbols and the chemical composition of the compounds are shown in Table 4. The mineralogical composition depends on the mineralogical composition of the coarse and fine aggregate, and the type of cement of the original concrete. The minerals from the coarse and fine aggregate are responsible for maintain the properties of RCA as a suitable aggregate for concrete. The compounds from the cement paste, however, exert negative influence on RCA properties. The porosity of the paste and the presence of portlandite increases the weakness on ITZ, which decreases the strength of the concrete, consequently. However, comparing to another work, Bordy et 
al. (2017) found larger peaks of portlandite in a cement paste powder for using as filler. The samples were cured underwater for 90 days, preventing carbonation. Park et al. (2020) found similar results with this work after carry out an accelerated carbonation on RAC.

Figure 8 - Diffractogram of RAC

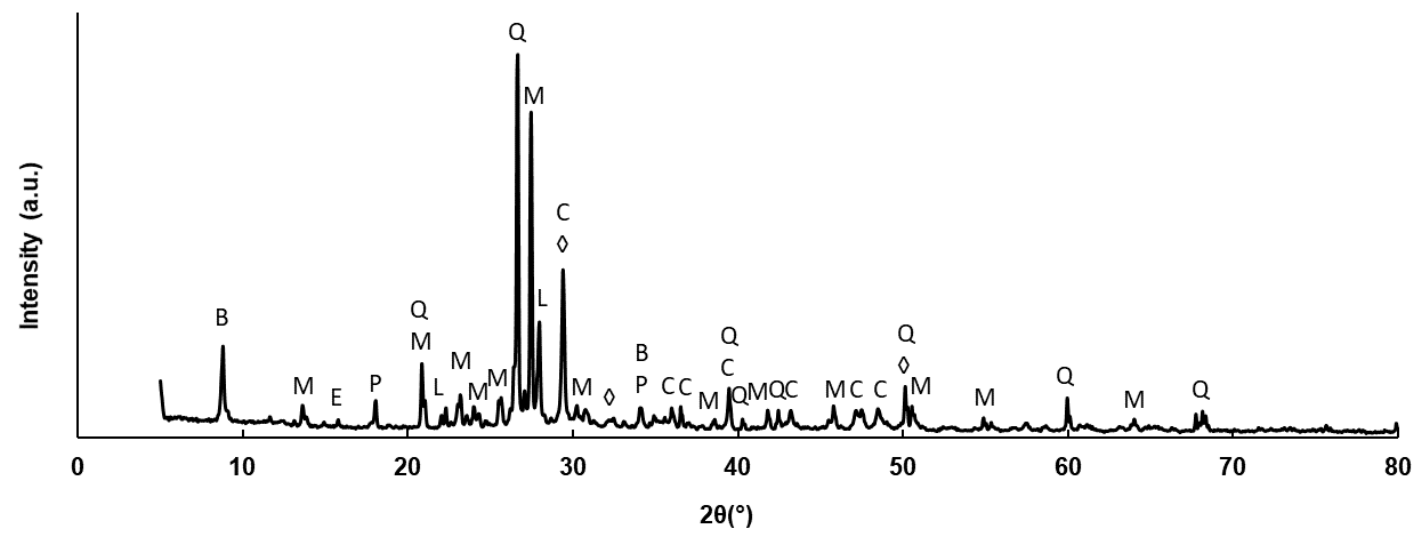

Source: Authors' authorship (2021)

Table 4 - Chemical composition and source of RCA mineralogical phases.

\begin{tabular}{llll}
\hline Symbol & Mineral name & Chemical formula & Source \\
\hline $\mathrm{Q}$ & Quartz & $\mathrm{SiO}_{2}$ & Fine and coarse aggregate \\
$\mathrm{C}$ & Calcite & $\mathrm{CaCO}_{3}$ & Cement paste \\
$\mathrm{M}$ & Microcline & $\mathrm{KAlSi}_{3} \mathrm{O}_{8}$ & Coarse aggregate \\
$\mathrm{B}$ & Biotite & $\mathrm{K}_{2}\left(\mathrm{Fe}_{2.8} \mathrm{Mg}_{2.3} \mathrm{Ti}_{0.6}\right)\left(\mathrm{Al}_{2.4} \mathrm{Si}_{5.6} \mathrm{O}_{20}\right)(\mathrm{OH})_{4}$ & Coarse aggregate \\
$\mathrm{P}$ & Portlandite & $\mathrm{Ca}(\mathrm{OH})_{2}$ & Cement paste \\
$\diamond$ & Calcium silicate hydrate & $\mathrm{Ca}{ }_{1.5} \mathrm{SiO}_{5.3} \cdot \mathrm{xH}_{2} \mathrm{O} / 1.5 \mathrm{CaO} . \mathrm{SiO}_{2 .} \times \mathrm{H}_{2} \mathrm{O}$ & Cement paste \\
E & Ettringite & $\mathrm{Ca}_{6}\left(\mathrm{Al}(\mathrm{OH})_{6}\right)_{2}\left(\mathrm{SO}_{4}\right)_{3}\left(\mathrm{H}_{2} \mathrm{O}\right)_{25.7}$ & Cement paste \\
$\mathrm{L}$ & Labradorite & $\mathrm{Ca}_{0.6} \mathrm{Na}_{0.3}\left(\mathrm{Al}_{1.6} \mathrm{Si}_{2.4} \mathrm{O}_{8}\right)$ & Coarse aggregate \\
\hline
\end{tabular}

TGA/DSC evaluations revealed the chemical and mineralogical composition of RCA. The mass loss peak at $82^{\circ} \mathrm{C}$ is due to the water loss of $\mathrm{C}-\mathrm{S}-\mathrm{H}$. The carbonation of the cement paste is noticeable due to the slight peak of portlandite at $446{ }^{\circ} \mathrm{C}$ and the remarkable peak at $733^{\circ} \mathrm{C}$ showing the presence of carbonates. Since the waste is stored outdoor, the carbonation occurs faster, leading to a quick decrease of the portlandite 
amount. It can be considered an improvement on RAC properties, since portlandite does not offer any resistance contribution and is easily leachable, polluting groundwater and rivers, and bringing damage to the environment (PARK et al., 2020).

Figure 9 - TGA/DTG (A) and DSC (B) results of RCA.
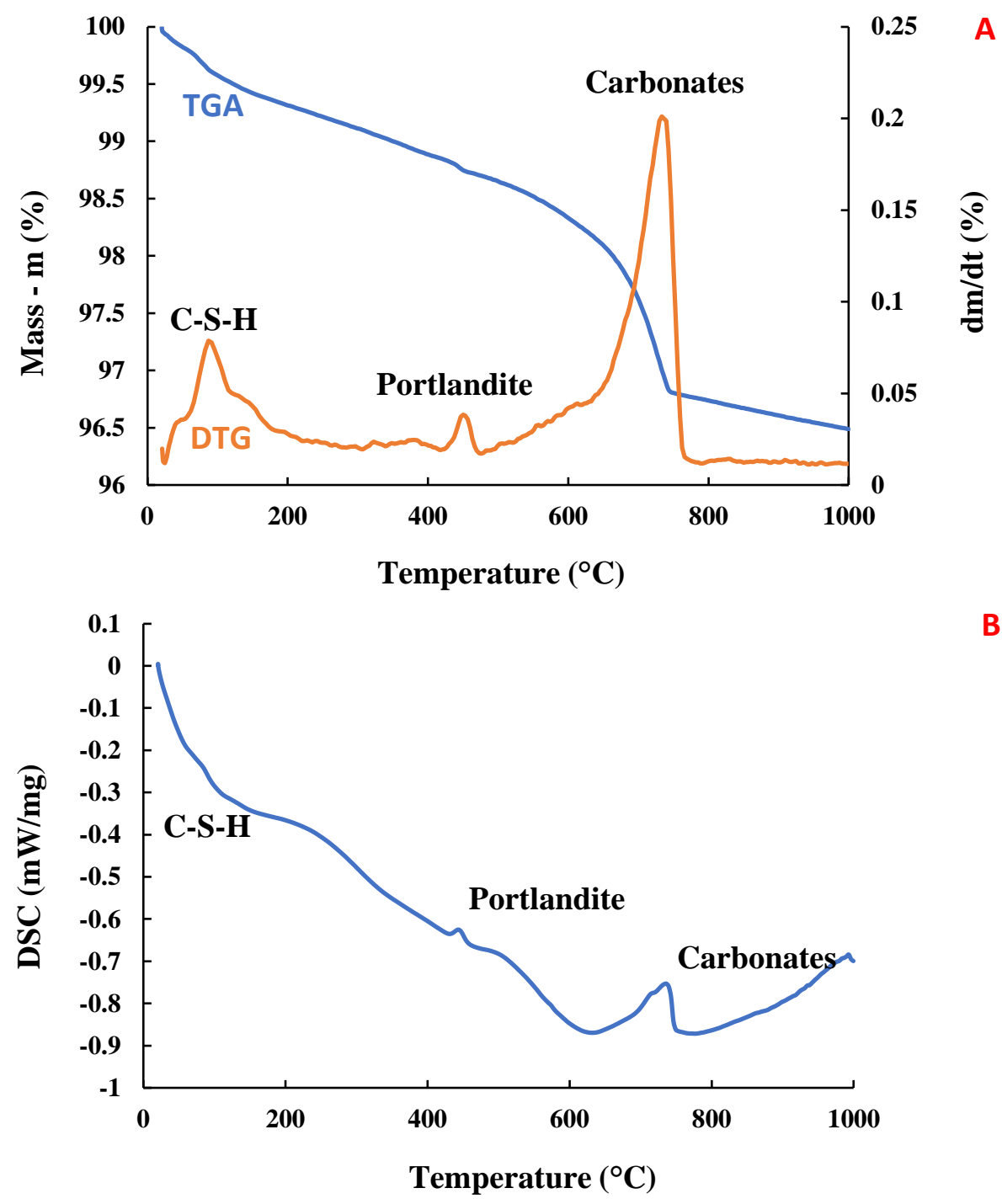

B

Source: Authors' authorship (2021)

The optical microscopy on RAC revealed the presence of its different phases, according to the methodology of the Brazilian Standard NBR 15577-3 (ABNT, 2018). Cracks appear next to the coarse aggregate and expose the effect of the crushing (Figure $10 \mathrm{a}, \mathrm{c})$. Besides reducing the strength of the recycled aggregate, the cracks and microcracks increase the necessary specific area to saturate the aggregate with water. However, the main reason for increasing the water absorption is the presence of pores in 
the cement paste. It is clear in the optical microscopy (Figure 10b) the presence of large and small pores, which raise the specific area of the aggregate. Also, from the optical microscopy, it can be seen (figure 10d) the presence of plagioclase and quartz phases of the coarse aggregate adhered to the cement paste.

Figure 10 - Optical microscopy of RCA on the surface of (1) coarse aggregate, (2) Crack, (3) cement paste, (4) macropore, (5) microcline; (6) plagioclase, (7) polycrystalline quartz.

(a)

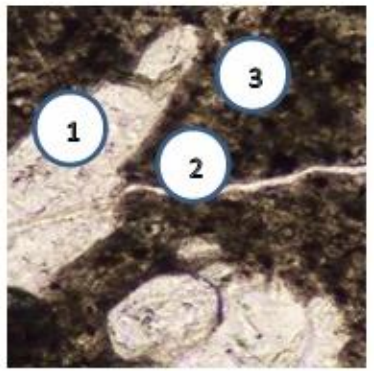

(c)

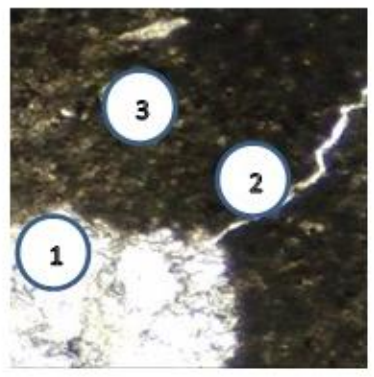

(b)

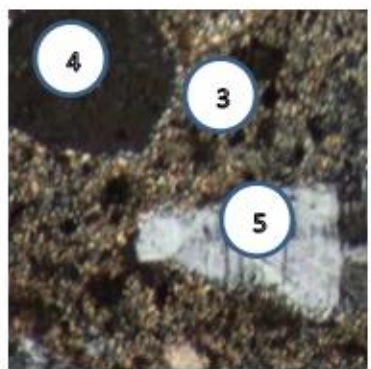

(d)

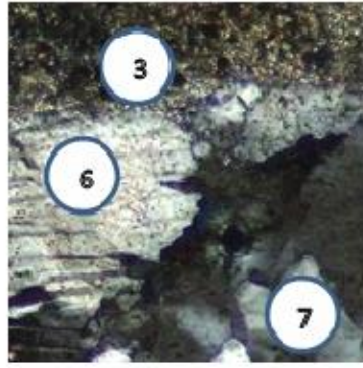

Source: Authors' authorship (2021)

Towards the original coarse aggregate, it was revealed the presence of biotite and plagioclase as main phases. The image (Figure 11) presents deformed and fractured structures in several spots. At first, it might be worrying from the point of the view of the alkali-silica reaction. However, the literature reports that primary crushed concrete may provide a safe aggregate in terms of alkali-silica reaction (ADAMS et al., 2013; BARRETO SANTOS; DE BRITO; SANTOS SILVA, 2020). Yet, re-crushed RAC presents higher values of expansion compared to the primary crushed RAC. 
Figure 11 - Optical microscopy of RCA with 5x lens magnification showing (1) plagioclase (labradorite) and biotite (2) phases.

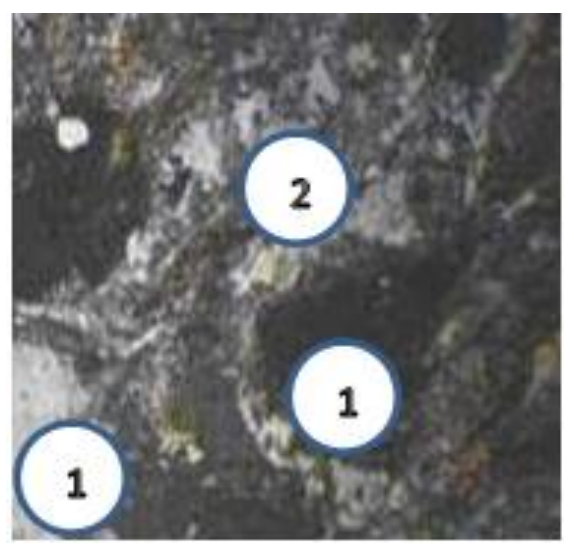

Source: Authors' authorship (2021)

Through SEM, hydrated phases of cement paste were identified on the adhered mortar of RCA. Figure 12 displays the presence of ettringite and calcite phase. Ettringite is easily identifiable due to its characteristic form of needles. Interestingly, though ettringite is a metastable phase, it was identified on the coarse aggregate even after at least two years from the initial hydration. The presence of ettringite was also identified by XRD (Figure 8). Visually, calcite was the most prevalent phase in the sample, followed by portlandite. This proves once again that the recycled aggregate contained a strongly carbonated hydrating cement paste. 
Figure 12 - SEM image for the adhered mortar on the RCA surface $(5.76 \mathrm{x})$.

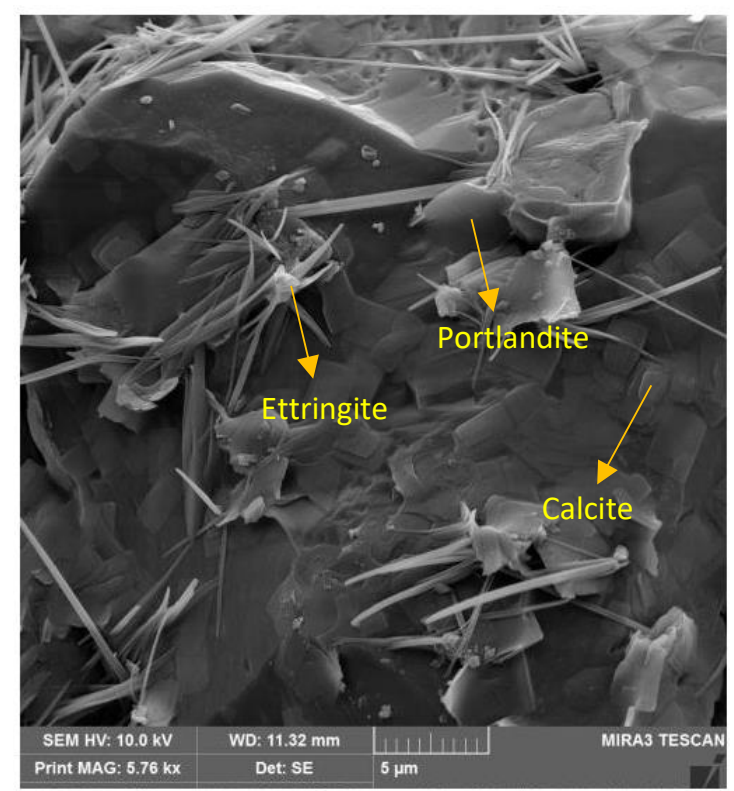

Source: Authors' authorship (2021)

Figure 13 shows a spongy-like and porous structure, which appeared many times during the assay. This porous structure can explain the higher water absorption and lower density compared to natural aggregate (AL-BAYATI et al., 2016). Its chemical composition was assessed using EDS which revealed the presence oxygen, calcium, carbon, silicon, aluminum, and sulfur. The presence of $\mathrm{Au}$ is due to the metallization of the sample. The presence of all these elements simultaneously and the high Ca content suggests that this structure is a carbonated Portland cement paste, with $\mathrm{C}-\mathrm{S}-\mathrm{H}$ and $\mathrm{CaCO}_{3}$ phases (SHAO et al., 2014). 
Figure 13 - SEM image (A) (5.72 x) and EDS (B) for a spongy-like structure in the adhered mortar of the RCA sample.

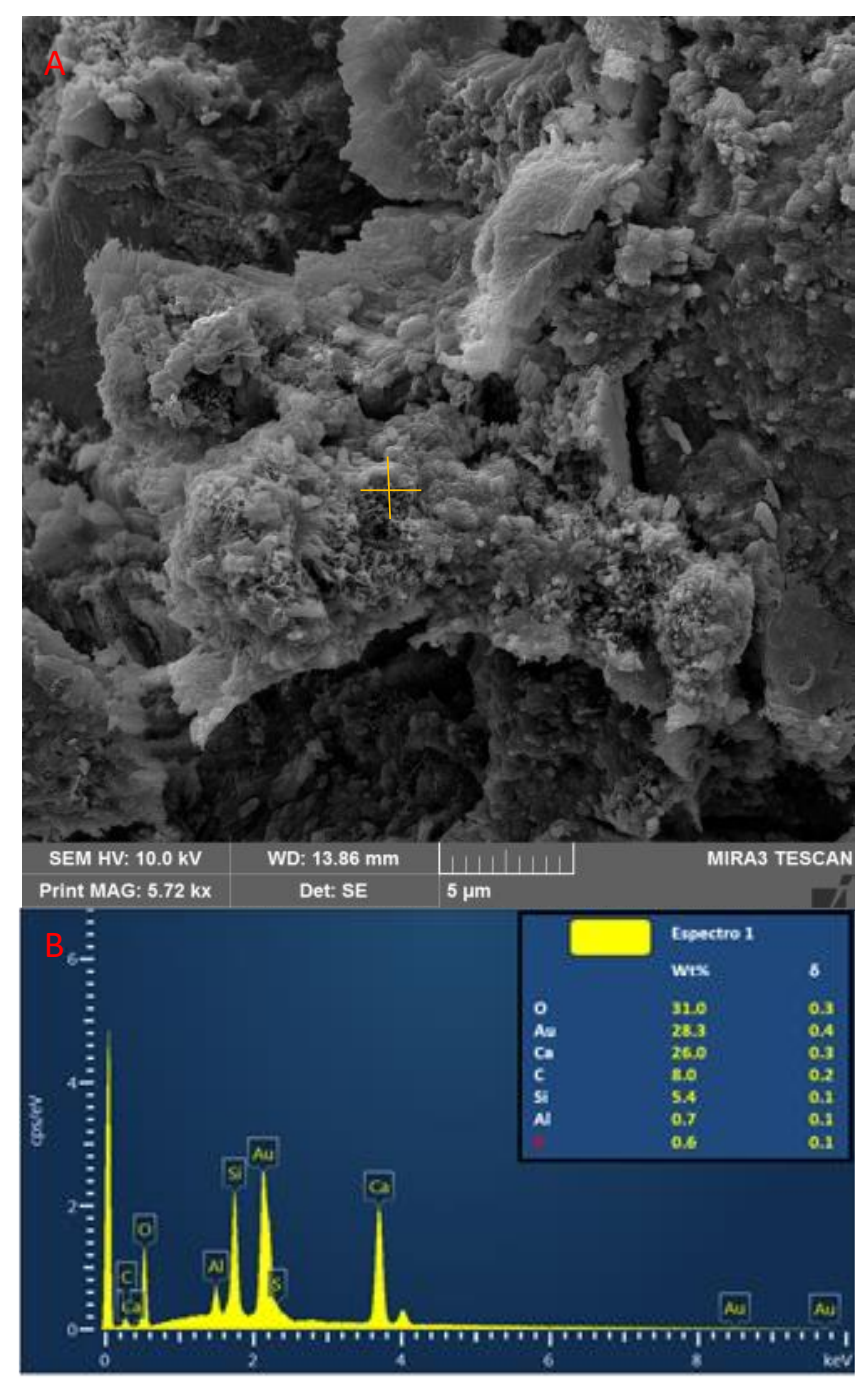

Source: authors' authorship (2021)

The process of carbonation can be also seen in Figure 14. This picture shows an agglomerate of carbonated portlandite surrounded by a fractured quartz particle. Note that there are several structures where portlandite and calcite may appear. Therefore, the utilization of SEM with EDS/EDX is crucial for the identification of these compounds. 
Figure 14 - SEM image (5.49 x) using EDS scanning for identifying Si and Ca elements.

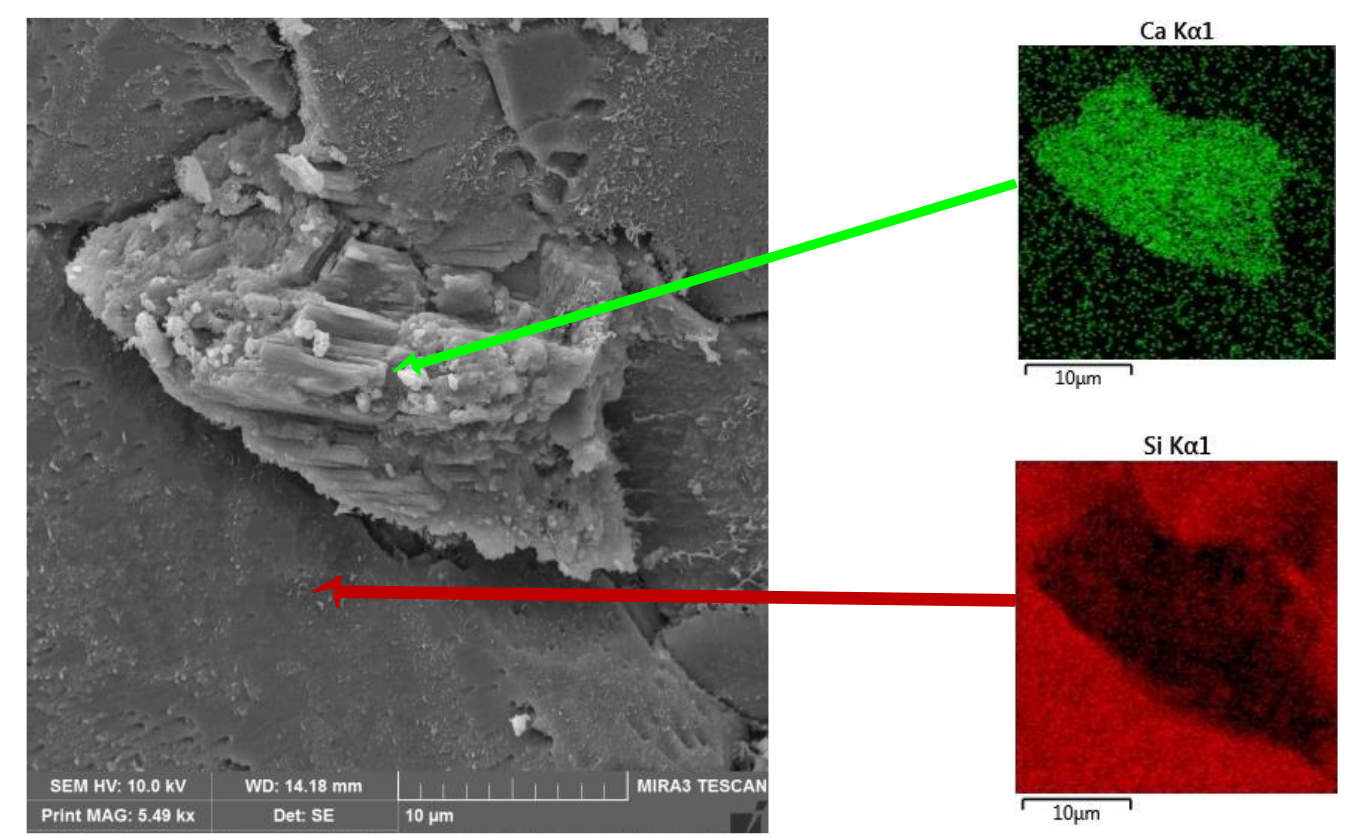

Source: authors' authorship (2021)

The results of the standardized aggregate's characterization are displayed in Table 2. The particle density value of the RCA was on average $6.5 \%$ lower than that NA, while the water absorption was 24 (AFR) and 14 (AR 4.8) times higher. It has been reported that, due to the porosity of the mortar, RCA density tend to be slightly lower compared to natural aggregate (CABRAL et al., 2010; KURDA; DE BRITO; SILVESTRE, 2017; SOARES et al., 2014). The powder material showed also higher value in comparison to NA, as expected. These RCA properties are a challenge to make this material feasible as an aggregate for concrete, as it is immediately clear that concrete with RCA will have a lower density and higher water absorption.

In a microstructural perspective, the micropores and cracks were identified in the structure of adhered mortar of RCA are the main responsible for the tremendous increase in the water absorption, because of the increase on the superficial area to saturate the aggregate with water. This also influences the density of the aggregate, and consequently, the physical and mechanical properties of concrete.

However, even with a reasonable amount of mortar adhered, Los Angeles wear value was not superior to natural aggregates. The recycled aggregate RG6.3 showed a 
higher wear value than the natural aggregate, in the case of G12, and lower in comparison to G19, whose value was $25.67 \%, 20.48 \%$, and $26.49 \%$, respectively. Recycled aggregates usually show higher wear than natural aggregates due to the lower strength of their adhered mortar.

\section{Fresh state properties}

In this study, the slump value of concrete with RCA was kept constant, according to each control concrete (FC-control and NSC-control), to achieve desired results. Their water content changed (slightly) to obtain the target workability. The fresh concrete bulky density of the recycled concrete mixes was lower than the control concrete mixes, in both cases; almost 3\% (FC-30) and 7\% (FC-50) in comparison to FC-control, and 12\% (NSC100) compared to NSC-control. In general, the trend was to decrease the slump value as the RCA amount increases, due to the high value of water absorption of RCA (GHORBANI et al., 2019). However, this behavior is not a consensus in the literature. Poon, Koon, and Lam (2007) concluded that RA from construction and demolition waste improved the workability of concrete with fly ash. Soares et al. (2014) presented that RCA did not influence in concrete slump values. Further, similar results were found by Kurda, Brito, and Silvestre (2017). As shown in Table 5, in the present work, even with a high absorption value, RCA did not significantly influence slump test result. This occurred because RCA composition for flowing concrete (50\% RFS + 50\% RA4.8) presented a greater size diameter than RFS. In the fresh density, however, RCA presented a remarkable effect, leading to decrease the values as RCA amount increased.

Table 5 - Results of slump test and fresh density.

\begin{tabular}{ccc}
\hline Nomenclature & $\begin{array}{c}\text { Slump test } \\
(\mathbf{m m})\end{array}$ & Fresh density $\left(\mathbf{g} / \mathbf{c m}^{\mathbf{3}}\right)$ \\
\hline FC-control & 240 & 2.45 \\
FC-30 & 230 & 2.38 \\
FC-50 & 220 & 2.27 \\
NSC-control & - & 2.47 \\
NSC-100 & - & 2.18 \\
\hline
\end{tabular}




\section{Water absorption, void index, and density}

RCA has a greater absorption capacity when compared to natural aggregate. Therefore, as concrete in this research is composed of $73-75 \%$ of aggregate, it is expected that concrete with RCA presents a higher water absorption when compared to the control mix. Results of water absorption, void index, and density are presented in Table 6. After 72h, FC-30 and FC-50 showed a water absorption of 3.55 and 4.08, respectively $22.8 \%$ and $41.2 \%$ higher than the FC-control mixture. This increase in porosity is also remarkable by the increase in void index and density as the RCA amount increases. These results are similar to what has been found in the literature (GHORBANI et al., 2019; LI, 2008; OMARY; GHORBEL; WARDEH, 2016).

Table 6 - Results of water absorption, void index, hardened density and splitting tensile strength for concrete mixtures.

\begin{tabular}{llllll}
\hline & FC-control & FC-30 & FC-50 & $\begin{array}{c}\text { NSC- } \\
\text { control }\end{array}$ & NSC-100 \\
\hline Water absorption $-72 \mathrm{~h}(\%)$ & 2.89 & 3.55 & 4.08 & 2.57 & 6.15 \\
Void index & 0.069 & 0.082 & 0.093 & 0.061 & 0.128 \\
Density $\left(\mathrm{kg} \cdot \mathrm{m}^{-3}\right)$ & $2,375.30$ & $2,312.40$ & $2,272.10$ & $2,371.30$ & $2,088.00$ \\
Splitting tensile strength (MPa) & 6.03 & 6.09 & 5.10 & 4.96 & 4.75 \\
\hline
\end{tabular}

As seen in Figure 15, the difference in results between NSC-control and NSC-100 mixtures was tremendously greater than in FC mixes. It occurred due to the total replacement of fine and coarse natural aggregate by the recycled aggregates, leading to an increase in the amount the aggregate with high water absorption. Furthermore, extruded dry concrete had a lacking quality control to evaluate its adequate consistency, and this fact made the finding of optimum water content difficult. 
Figure 15 - Evolution of water absorption over time.

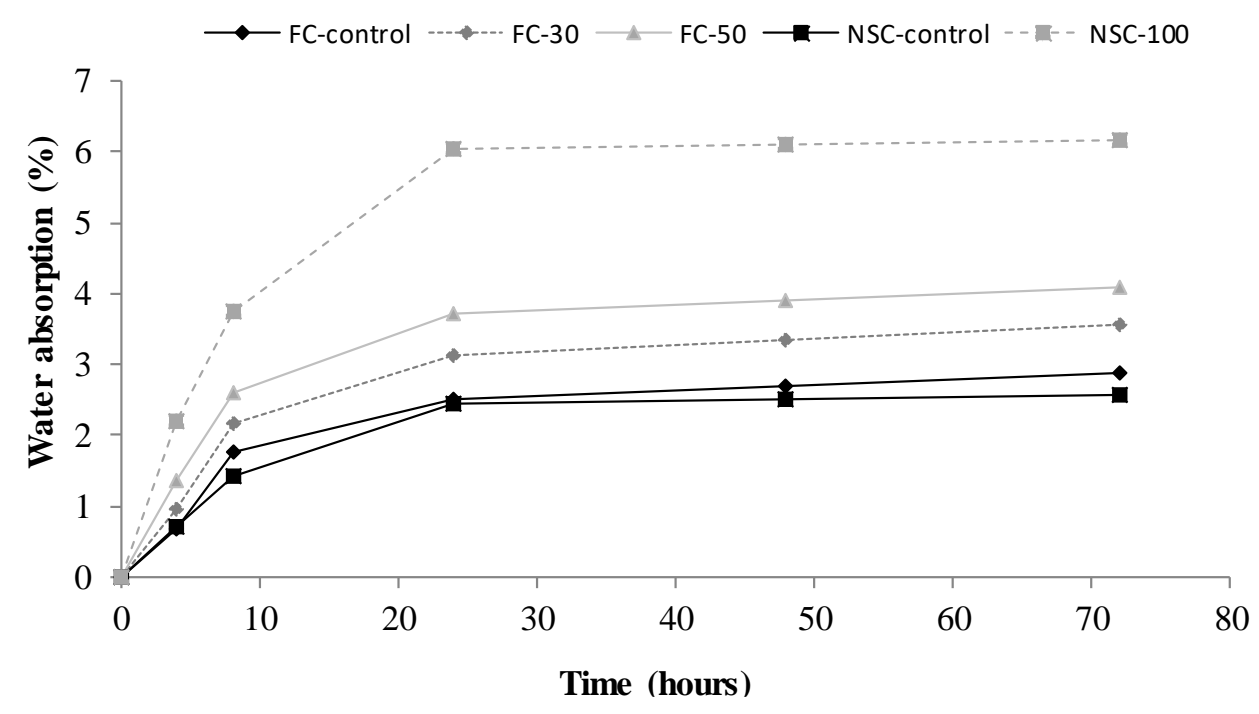

Source: authors' authorship (2021)

\section{Splitting tensile strength}

In general, splitting tensile strength decreases as the amount of RCA increases(AJDUKIEWICZ; KLISZCZEWICZ, 2002; LI, 2008; SOARES et al., 2014). However, Brito et al. (2016) found an increase in this property with the incorporation of RCA (Table 6). In this research, no trend of increase or decrease has been seen regarding flow concrete. FC-30 showed a slight increase compared to FC-control and FC-50 had the lowest value than the others. In NSC mixes, NSC-100 showed a lower value of splitting tensile strength compared to NSC-control, but disproportionate to the strong decrease in compressive strength. Therefore, no trend of increase or decrease was observed due to the incorporation of RCA.

\section{Dynamic and static modulus of elasticity}

Modulus of elasticity (ME) was seriously affected by the RCA incorporation. Just like the water absorption and density, the increase in porosity results in a decrease of concrete stiffness, hence decreasing the modulus of elasticity. In the literature, the decrease in the modulus of elasticity varies between 10 to $40 \%$, depending on the RCA content (KHATIB, 2005; OMARY; GHORBEL; WARDEH, 2016; RAHAL, 2007; SOARES et al., 2014). 
Figure 16 shows the results of the dynamic and static modulus of elasticity. FCcontrol showed values about 2 to $3 \%$ higher for dynamic ME and 3 to $8 \%$ for static ME. In the dry mixtures, the percentual difference of NSC-control to NSC-100 was $29.2 \%$ for dynamic ME and 54.7\% higher for static ME.

The relationship between the compressive strength and the other properties was detailed in another article (ESTOLANO et al., 2018). The conclusions from this paper were that modulus of elasticity did not present a good relationship with the compressive strength, because, while the compressive strength was not affected by the incorporation of RAC, the modulus of elasticity decreased significantly. In this context, the increase in the porosity showed by water absorption and density tests presented a strong relationship with the modulus of elasticity.

Figure 16 - Results of dynamic and static modulus of elasticity

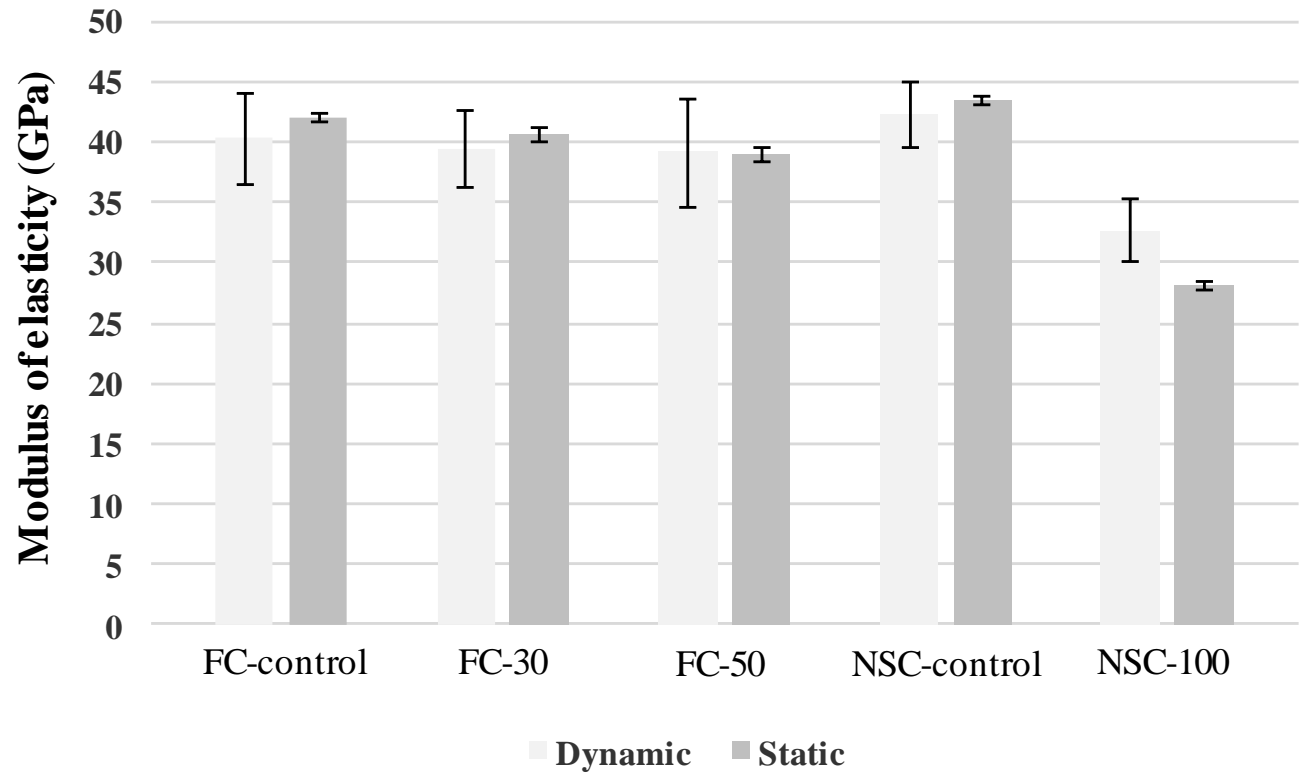

Source: authors' authorship (2021)

\section{Compressive strength}

Considering the flowing concrete mixtures, results of compressive presented no trend of increase or decrease as the RCA amount increased and samples presented close values among them (Figure 17). At 105 days, FC-30 presented the higher compressive strength value, reaching 87.13 MPa. Theoretically, an increase in the diameter size of RCA composition should lead to an increase in the porosity. However, 
there are reasonable explanations to support the slight reduction or keeping of compressive strength values of concrete with RCA, when compared to reference concrete. The presence of cement, even if hydrated, can contribute to improving the mechanical properties of concrete. It happens because in concrete products, cement hydrates continuously, and its non-hydrated fraction can contribute as anhydrous cement in the concrete matrix.

Thus, it can be concluded that RCA, mainly as fine particles, can enhance the total cement amount in concrete, and consequently decrease the water/cement ratio. Bordy et al.(2017) found a value of $24 \%$ corresponding to the amount of anhydrous cement in fine RCA for use as a filler in concrete. This value varies according to the proportion of materials used and the age of the concrete.

Figure 17 - Compressive strength evolution of flowing concrete mixtures.

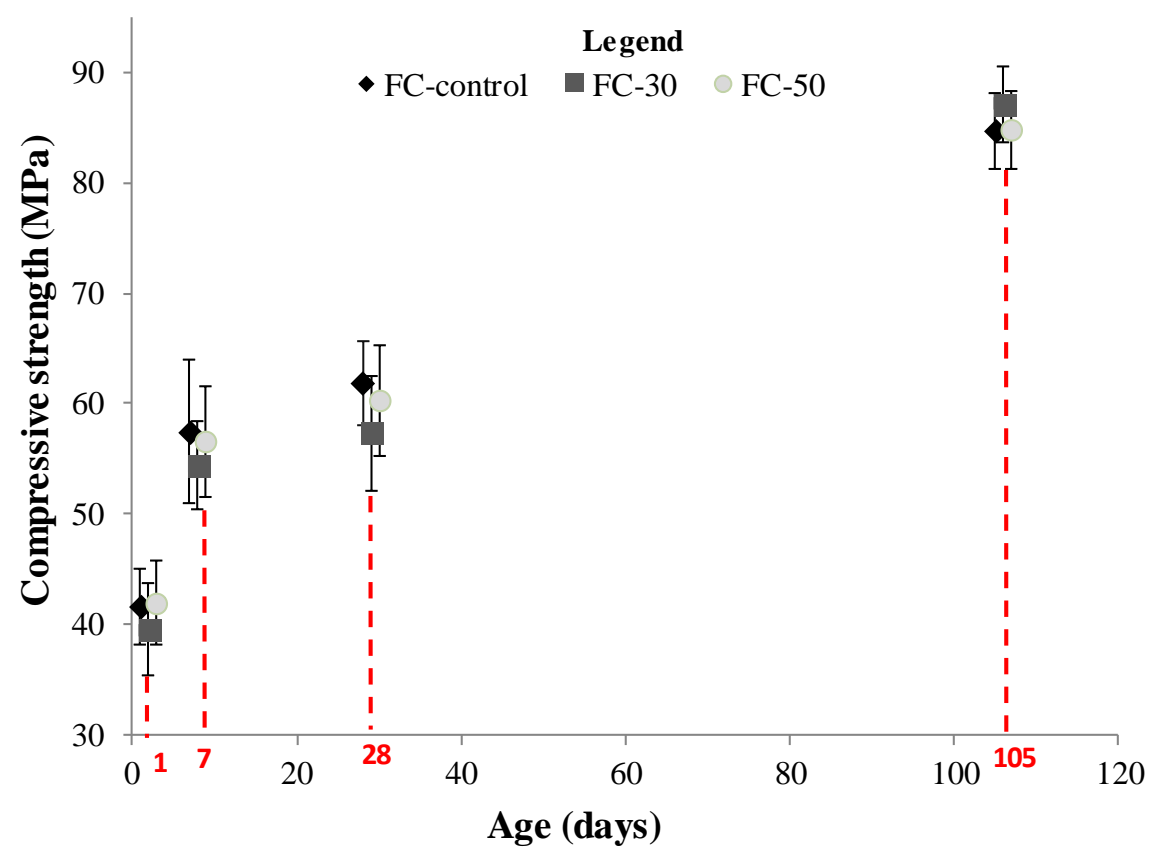

Source: authors' authorship (2021)

The use of $100 \%$ of RCA in coarse and fine aggregate led to a strong decrease in compressive strength (Figure 18). NSC showed being a more sensible kind of concrete regarding compaction. The reduction in the compressive strength reached about $20 \mathrm{MPa}$ in 105 days, corresponding to $26.8 \%$. Some reasons can explain this phenomenon. Therefore, the use of $100 \%$ of RCA strongly influenced the particle packing and created 
voids. Even so, the NSC-100 mixture presented a compressive strength greater than 25 $\mathrm{MPa}$, the minimum value required for safely hoisting the concrete slabs.

Figure 18 - Compressive strength evolution of no-slump mixtures.

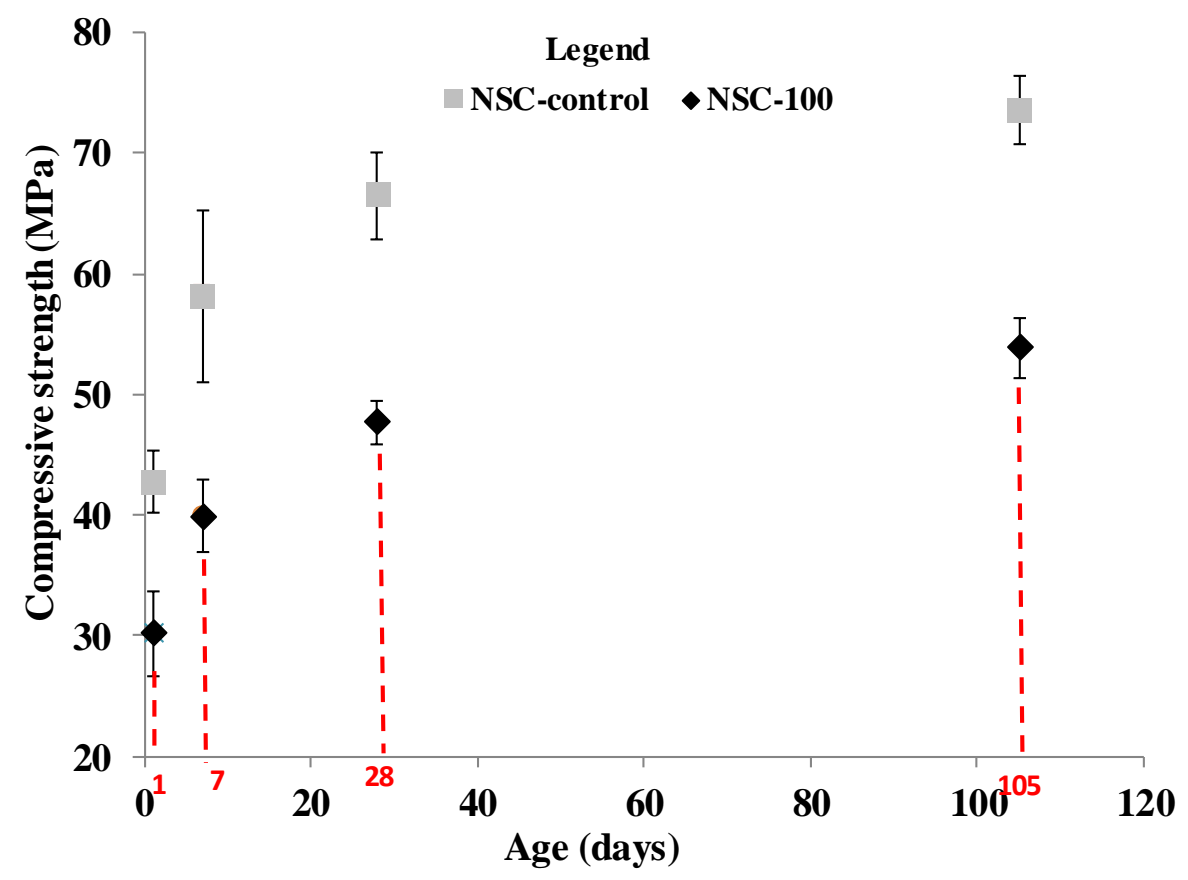

Source: Authors' authorship (2021)

\section{Statistical analysis}

As explained previously, the compressive strength of flowing concretes showed similar results among each other. Therefore, only employing a statistical analysis it is possible to conclude if the results are different from each other. At first, outlier tests indicated that none of the samples showed any aberrant points. After, Anderson-Darling tests showed that all the samples fitted in the normal distribution, as none of the p-values was less than 0.05 . Table 7 presents the results of outliers and normality analysis. 
Table 7 - Analysis of outliers and normality on compressive strength results

\begin{tabular}{|c|c|c|c|c|c|c|}
\hline \multirow{2}{*}{$\begin{array}{c}\text { Age } \\
\text { (days) }\end{array}$} & \multirow{2}{*}{ Concrete type } & \multirow{2}{*}{$\begin{array}{l}\text { Numberof } \\
\text { samples }\end{array}$} & \multirow{2}{*}{$\begin{array}{r}\text { Mean } \\
(\text { MPa) }\end{array}$} & \multirow{2}{*}{$\begin{array}{l}\text { Numberof } \\
\text { outliers }\end{array}$} & \multicolumn{2}{|c|}{ Anderson-Darling Test } \\
\hline & & & & & p-value & Normal distribution \\
\hline \multirow{5}{*}{1} & FC-control & 18 & 41.52 & 0 & 0.288 & Yes \\
\hline & FC-30 & 18 & 39.53 & 0 & 0.426 & Yes \\
\hline & FC-50 & 18 & 41.89 & 0 & 0.287 & Yes \\
\hline & NSC-0 & 8 & 42.71 & 0 & 0.141 & Yes \\
\hline & NSC-100 & 8 & 30.20 & 0 & 0.073 & Yes \\
\hline \multirow{5}{*}{7} & FC-control & 18 & 57.46 & 0 & 0.167 & Yes \\
\hline & FC-30 & 18 & 54.36 & 0 & 0.055 & Yes \\
\hline & FC-50 & 18 & 56.52 & 0 & 0.931 & Yes \\
\hline & NSC-0 & 8 & 58.12 & 0 & 0.352 & Yes \\
\hline & NSC-100 & 8 & 39.90 & 0 & 0.453 & Yes \\
\hline \multirow{5}{*}{28} & FC-control & 18 & 61.89 & 0 & 0.57 & Yes \\
\hline & FC-30 & 18 & 57.3 & 0 & 0.097 & Yes \\
\hline & FC-50 & 18 & 60.32 & 0 & 0.881 & Yes \\
\hline & NSC-0 & 8 & 66.46 & 0 & 0.65 & Yes \\
\hline & NSC-100 & 8 & 47.68 & 0 & 0.81 & Yes \\
\hline \multirow{5}{*}{105} & FC-control & 18 & 84.69 & 0 & 0.259 & Yes \\
\hline & FC-30 & 18 & 87.13 & 0 & 0.946 & Yes \\
\hline & FC-50 & 18 & 84.81 & 0 & 0.801 & Yes \\
\hline & NSC-0 & 8 & 73.58 & 0 & 0.361 & Yes \\
\hline & NSC-100 & 8 & 53.86 & 0 & 0.886 & Yes \\
\hline
\end{tabular}

Right after, obeying the statistical protocol, T-test for means and ANOVA showed if the samples were statically different or not (Table 8). At 1 day, the concrete precast elements must have at least $35 \mathrm{MPa}$ for hoisting. In addition to all the results showing a 
mean greater than $35 \mathrm{MPa}$ with 1 day, FC-control did not present statistical difference with FC-30 and FC-50. At 105 days, FC-50 showed the highest result of compressive strength, but it was statistically equal to FC-control. The FC-30 sample showed a slightly lower value than the other two, and the difference was less than $3 \mathrm{MPa}$.

Therefore, from the statistical analysis in the flowed concrete, the replacement of natural sand by the composition RFS + AR4.8 did not result in a decrease in strength. One hypothesis for this to have occurred is that the hydration of anhydrous cement in the RCA, which can reach significant values as shown by Bordy et al. (2017), compensated the increase in porosity and the slight increase in w/c ratio. In addition, there was no influence in the concrete compacting since the workability between the mixtures was similar. Therefore, the strategy of using an aggregate composition with a greater specific surface proved to be adequate.

In NSC mixtures, the p-values were very close to zero, confirming that the NSC100 mixture showed a significant decrease in compressive strength. 
Table 8 - Statistical analysis of compressive strength data.

\begin{tabular}{|c|c|c|c|c|c|}
\hline Age (days) & Concrete type 1 & Concrete type 2 & $\begin{array}{c}\text { p-value (T- } \\
\text { test) }\end{array}$ & $\begin{array}{c}\text { p-value } \\
\text { (ANOVA) }\end{array}$ & Samples are statiscally different? \\
\hline \multirow{4}{*}{1} & FC-control & FC-30 & 0.144 & 0.133 & No \\
\hline & FC-30 & FC-50 & 0.018 & - & Yes \\
\hline & FC-50 & FC-control & 0.718 & 0.762 & No \\
\hline & NSC-0 & NSC-100 & 0.000 & - & Yes \\
\hline \multirow{4}{*}{7} & FC-control & FC-30 & 0.098 & 0.093 & No \\
\hline & FC-30 & FC-50 & 0.190 & 0.163 & No \\
\hline & FC-50 & FC-control & 0.561 & 0.629 & No \\
\hline & NSC-0 & NSC-100 & 0.000 & - & Yes \\
\hline \multirow{4}{*}{28} & FC-control & FC-30 & 0.019 & - & Yes \\
\hline & FC-30 & FC-50 & 0.077 & 0.087 & No \\
\hline & FC-50 & FC-control & 0.272 & - & Yes \\
\hline & NSC-0 & NSC-100 & 0.000 & - & Yes \\
\hline \multirow{4}{*}{105} & FC-control & FC-30 & 0.038 & - & Yes \\
\hline & FC-30 & FC-50 & 0.023 & - & Yes \\
\hline & FC-50 & FC-control & 0.911 & 0.919 & No \\
\hline & NSC-0 & NSC-100 & 0.000 & - & Yes \\
\hline
\end{tabular}

\section{Surface hardness}

The surface hardness test was evaluated as a non-destructive alternative to the compressive strength test on concrete specimens. The rebound hammer applied to concrete parts is known to provide reasonable estimates of the mechanical properties of concrete. However, in concrete specimens, this type of evaluation is rare to find in the literature.

At first, it was found that a problem in carrying out this test would be the cylindrical geometry of the specimen, which would prevent the correct application of the blow. However, it was found that such a limitation did not prevent the achievement of consistent 
results with an acceptable standard deviation. Table 9 shows that the standard deviation values were between 0.90 and 3.08 , with a maximum variation coefficient $(100 \% *$ standard / average) of $8.61 \%$.

The fluid mixtures present close values, as well as the compressive strength. In noslump mixtures, the control mix showed results slightly higher than NSC-100. Except for NSC-100 at 1 day, all other mixtures have a rebound number/compressive strength (RN/CS) ratio of less than 1.00 .

Table 9 - Results of rebound number and RN/CS ratios at 1, 7 and 28 days. Standard deviation values in parentheses.

\begin{tabular}{|c|c|c|c|c|c|c|}
\hline \multirow{2}{*}{ Nomenclature } & \multicolumn{2}{|c|}{1 day } & \multicolumn{2}{|c|}{7 days } & \multicolumn{2}{|c|}{28 days } \\
\hline & $\mathrm{RN}^{*}(\mathrm{MPa})$ & $\mathrm{RN} / \mathrm{CS}$ ratio & $\mathrm{RN}^{*}(\mathrm{MPa})$ & $\begin{array}{l}\mathrm{RN} / \mathrm{CS} \\
\text { ratio }\end{array}$ & $\mathrm{RN}^{*}(\mathrm{MPa})$ & $\begin{array}{l}\mathrm{RN} / \mathrm{CS} \\
\text { ratio }\end{array}$ \\
\hline FC-control & $30.63(2.23)$ & 0.74 & $35.77(3.08)$ & 0.63 & $39.87(1.41)$ & 0.65 \\
\hline FC-30 & $30.21(1.93)$ & 0.77 & $38.69(2.36)$ & 0.71 & 39.04(1.96) & 0.68 \\
\hline FC-50 & $31.59(1.85)$ & 0.76 & $38.62(1.41)$ & 0.69 & $40.76(1.35)$ & 0.68 \\
\hline NSC-control & $35.65(1.21)$ & 0.83 & $39.55(1.89)$ & 0.69 & $43.06(1.85)$ & 0.65 \\
\hline NSC-100 & $31.99(1.19)$ & 1.07 & $33.94(0.90)$ & 0.85 & $37.14(0.98)$ & 0.78 \\
\hline
\end{tabular}

Analyzing the point cloud between the rebound number and compressive strength data (Figure 19), there is a clear correlation between the two properties. Analyzing the data by type of concrete, there is a remarkable relationship between properties, presenting a correlation considered strong according to Dantas (1998) ( $\left.\mathrm{R}^{2}>0.8\right)$. In an individual analysis by mixture, the values of $\mathrm{R}^{2}$ varied between 0.6 and 0.9 . 
Figure 19 - Relation between rebound number and compressive strength for flowing (A) and no-slump mixes (B).

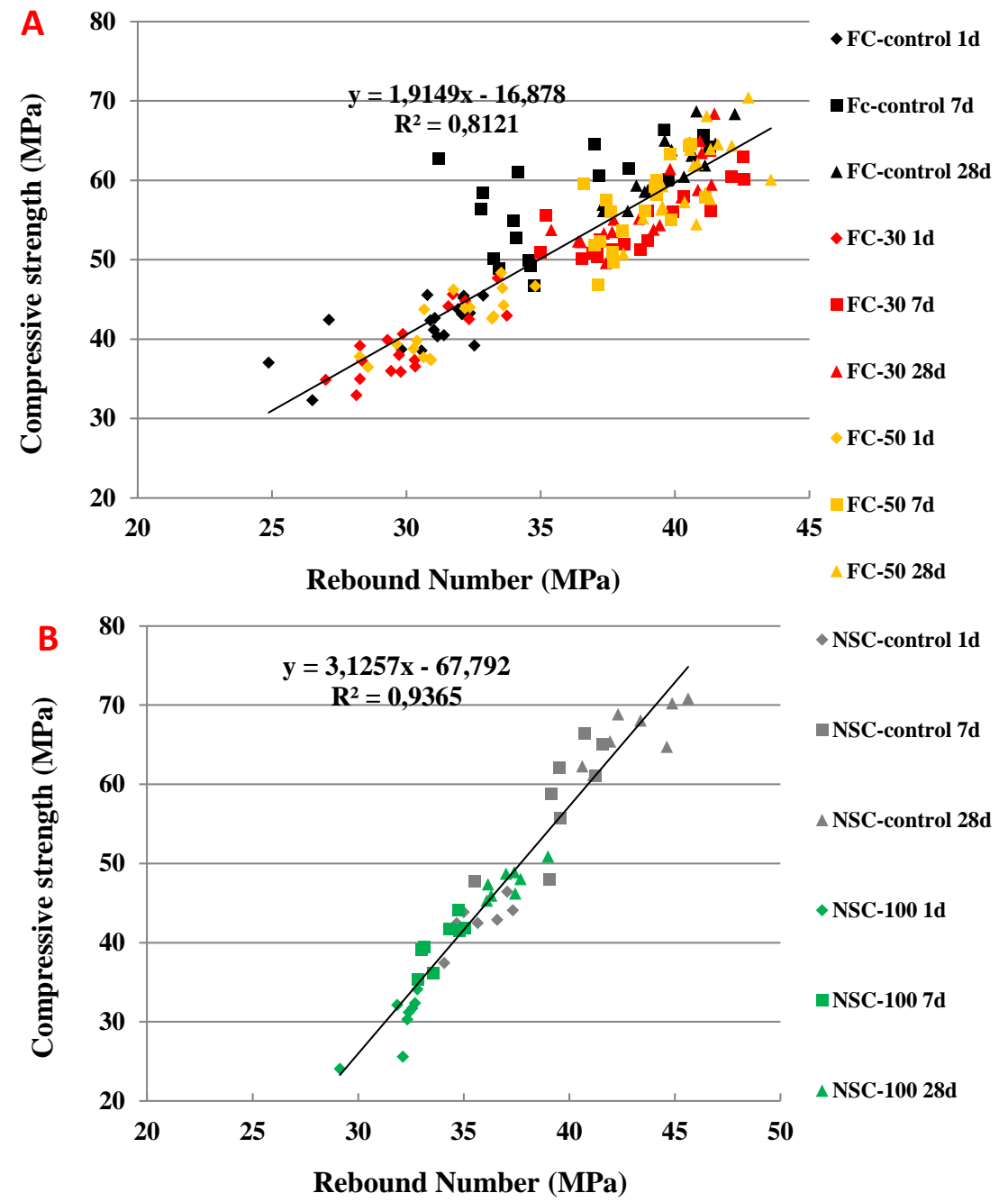

Source: authors' authorship (2021)

\section{CONCLUSIONS}

A strategy was proposed to recycle the concrete waste in the precast plant (Figure 20). It is worth notice that this research was carried out on a laboratory scale, using a small mill, and then the use of recycled aggregate was limited to concrete produced in the laboratory. This research was important to show to the top of the company that the use of recycled aggregate was feasible. From this, new steps were advanced, such as studying production of recycled aggregate began on an industrial scale and analyzing the cost of implementing a recycling plant. 
Figure 20 - Flow chart proposed for the industrial application of RCA

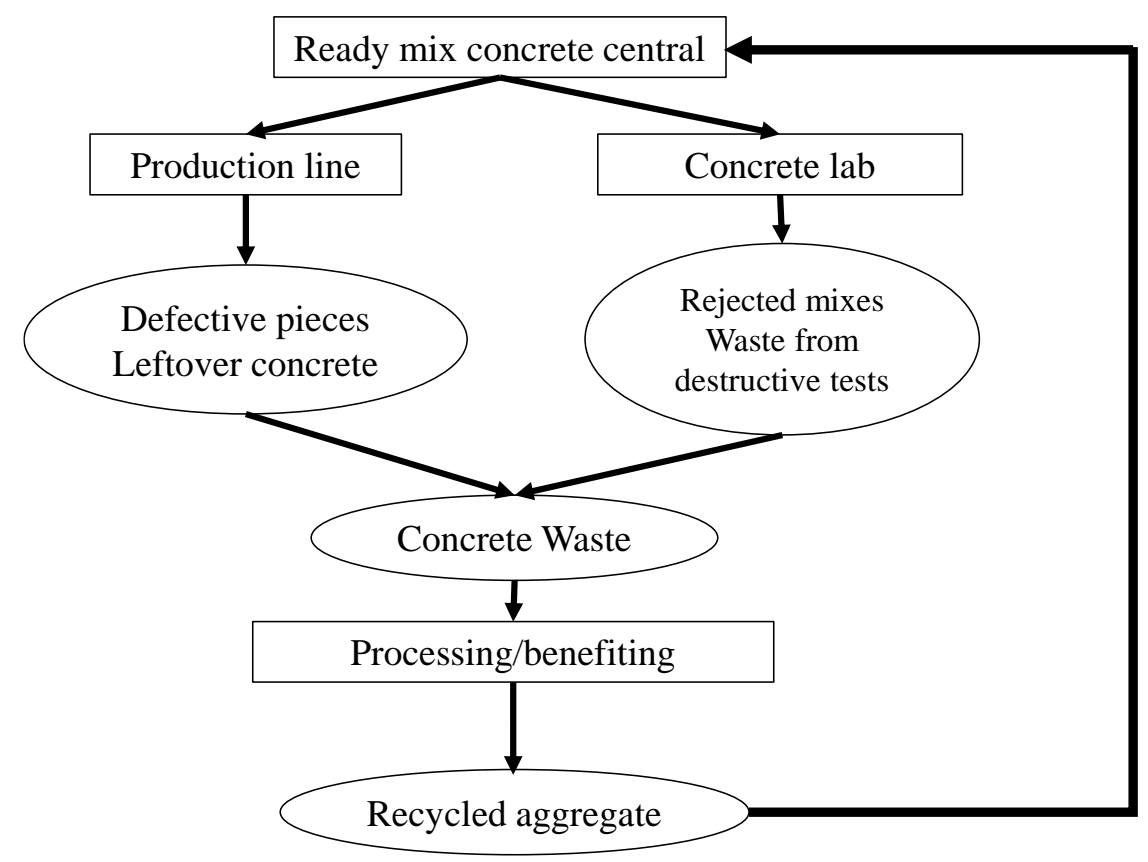

Source: authors' authorship (2021)

Briefly, in flowing concrete, the incorporation up to $50 \%$ of recycled aggregate into the fine fraction did not significantly influence in compressive strength, however led to increase the concrete porosity, what strongly influenced other properties. On the other hand, no-slump concrete with $100 \%$ RCA presented a strong deterioration in mechanical performance. Nevertheless, all mixes with recycled aggregate showed high values of compressive strength than the minimum requested at 1 day after casting. Thus, the main conclusions are as follows:

- The RCA's characterization revealed a strongly carbonated, porous and cracked structured. It increases the water absorption and decrease the density of RCA. However, the carbonation mitigates the effect of the presence of portlandite, such as leaching and pollution.

- SEM evaluation presented a diversity of phases and structures such as portlandite, carbonates and C-S-H. Ettringite was identified by XRD and SEM even after at least two years from the primary hydration. 
- To maintain the workability between the mixtures of fluid concrete, it was necessary to subtly increase the w/c ratio for concretes with RCA, which did not significantly influence the mechanical properties. Therefore, the effect of RCA on the workability of fluid concrete was very little or none.

- In dry mixes, it was necessary to strongly increase the w/c ratio to maintain an adequate consistency for extrusion. Therefore, the total substitution of recycled sand and natural gravel has strongly increased the demand for water.

- Though there was no significant variation in the w/c ratio, the change in the packaging of the particles resulted in an increase in porosity, and consequently an increase in water absorption and voids index and a decrease in density and elasticity module.

- Regarding the results of splitting tensile strength, no trend was observed in both flowing or no-slump concrete mixtures.

- The statistical analysis showed that there was no influence of the incorporation of RCA in the fluid concrete. However, in dry concrete, the significant decrease in mechanical performance was observed. It shows that other methods of consistency analysis for extrusion must be studied to obtain an optimal w/c ratio.

- The employment of the rebound hammer test on the side of the specimens proved to be a good tool to estimate the strength of the concrete. Performing the analysis by type of concrete showed greater precision than analyzing considering all the results.

\section{ACKNOWLEDGEMENTS}

The authors thank the Coordination of Superior Level Staff Improvement (CAPES) for the financial support of this research. The authors also thank Foundation to Support Science and Technology of Pernambuco (FACEPE), Brazilian National Concil of Research (CNPq) and Financier of Studies and Projects (FINEP), and L'Oréal-Unesco$\mathrm{ABC}$ for "Woman in Science". 


\section{REFERENCES}

ADAMS, Matthew P. et al. Applicability of the Accelerated Mortar Bar Test for AlkaliSilica Reactivity of Recycled Concrete Aggregates. Advances in Civil Engineering Materials v. 2, n. 1, p. 20120030 , 20 mar. 2013. Disponível em: <http://www.astm.org/doiLink.cgi?ACEM20120030>.

AJDUKIEWICZ, Andrzej; KLISZCZEWICZ, Alina. Influence of recycled aggregates on mechanical properties of HS/HPC. Cement and Concrete Composites v. 24, n. 2, p. 269-279, 2002.

AL-BAYATI, Hanaa Khaleel Alwan et al. Evaluation of various treatment methods for enhancing the physical and morphological properties of coarse recycled concrete aggregate. Construction and Building Materials v. 112, p. 284-298 , 2016. Disponível em: 〈http://dx.doi.org/10.1016/j.conbuildmat.2016.02.176>.

ARORA, Sumit; SINGH, S. P. Analysis of flexural fatigue failure of concrete made with 100\% Coarse Recycled Concrete Aggregates. Construction and Building Materials v. 102, p. 782-791, 2016.09500618.

ASSOCIAÇÃO BRASILEIRA DE NORMAS TÉCNICAS. ABNT NBR NM 67, Concrete - Slump test for determination of the consistency, Brazilian Association of Techincal Standards, Rio de Janeiro, Brazil. . [S.I: s.n.]. , 1998

NBR NM 67, Concrete - Slump test for determination of the consistency, Brazilian Association of Techincal Standards, Rio de Janeiro, Brazil., 1998

NBR NM 30, Fine aggregate - Test method for water absorption, Rio de Janeiro, 2001.

. NBR NM 51, Small-size coarse aggregate - Test method for resistance to degradation by Los Angeles machine, Rio de Janeiro, 2001.

NBR NM 248, Aggregates - Sieve analysis of fine and coarse aggregate, Rio de Janeiro, 2003.

NBR NM 46, Aggregates - Determination of material finer than 75 um sieve by washing, Rio de Janeiro, 2003. 
ASSOCIAÇÃO BRASILEIRA DE NORMAS TÉCNICAS. NBR 5739. Concrete compressive strength test with cylindrical specimens, Rio de Janeiro, 2007.

NBR 9778, Hardened mortar and concrete - determination of water absorption, void index and densit, Rio de Janeiro, 2009.

NBR NM 53, Coarse aggregate - Determination of the bulk specific gravity, apparent specific gravity and water absorption, Rio de Janeiro, 2009.

NBR 7222, Concrete and mortar - Determination of the tension strength by diametrical compression of cylindrical test specimens, Rio de Janeiro, 2011.

NBR 7584, Hardened concrete - Evaluation of surface hardness by reflecting esclerometer - Test method, Brazilian Association of Technical Standards, Rio de Janeiro, 2012.

AMERICAN SOCIETY FOR TESTING AND MATERIALS. C 597, Standard test method for pulse velocity through concrete, West Conschohocken, 2016.

BARRETO SANTOS, Miguel; DE BRITO, Jorge; SANTOS SILVA, António. A Review on Alkali-Silica Reaction Evolution in Recycled Aggregate Concrete. Materials v. 13, n. 11, p. 2625 , 9 jun. 2020. Disponível em: <https://www.mdpi.com/1996$1944 / 13 / 11 / 2625>$.

BORDY, Arthur et al. Cement substitution by a recycled cement paste fine: Role of the residual anhydrous clinker. Construction and Building Materials v. 132, p. 1-8 , 2017. Disponível em: <http://dx.doi.org/10.1016/j.conbuildmat.2016.11.080>.

Brazilian Association for Standardzation. NBR 15577-3 - Aggregates - alkali-activated reactivity. Part 3: petrographic analysis for evaluation of the potential reactivity of aggregates with alkali activated compounds from concrete. Rio de Janeiro. . [S.l: s.n.]. , 2018

CABRAL, Antonio Eduardo Bezerra et al. Mechanical properties modeling of recycled aggregate concrete. Construction and Building Materials v. 24, n. 4, p. 421-430 , 2010. Disponível em: <http://dx.doi.org/10.1016/j.conbuildmat.2009.10.011>.0950-0618.

DANTAS, Rubens Alves. Valuation expert - an introduction to scientific 
methodology. São Paulo: PINI, 1998. .

DE BRITO, J. et al. Structural, material, mechanical and durability properties and behaviour of recycled aggregates concrete. Journal of Building Engineering v. 6, p. 116 , 2016. Disponível em: <http://dx.doi.org/10.1016/j.jobe.2016.02.003>.23527102.

DE BRITO PRADO VIEIRA, Luiz; DOMINGUES DE FIGUEIREDO, Antonio; JOHN, Vanderley Moacyr. Evaluation of the use of crushed returned concrete as recycled aggregate in ready-mix concrete plant. Journal of Building Engineering v. 31, n. April, p. 101408 , 2020. Disponível em: <https://doi.org/10.1016/j.jobe.2020.101408>.

DOMINGO-CABO, A. et al. Creep and shrinkage of recycled aggregate concrete. Construction and Building Materials v. 23, n. 7, p. 2545-2553 , 2009. Disponível em: <http://dx.doi.org/10.1016/j.conbuildmat.2009.02.018>.

ESTOLANO, V. et al. Assessment of static and dynamic modulus of elasticity in concrete made with recycled aggregate from concrete precast rejects. Revista Materia v. 23, n. 1 , 2018.

EVANGELISTA, L; DE BRITO, J. Mechanical behaviour of concrete made with fine recycled concrete aggregates. Cement and Concrete Composites v. 29, n. 5, p. 397-401 , 2007.

GALVÍN, A. P. et al. Leaching assessment of concrete made of recycled coarse aggregate: Physical and environmental characterisation of aggregates and hardened concrete. Waste Management v. 34, n. 9, p. 1693-1704 , 2014.

GHORBANI, Saeid et al. Effect of crushed concrete waste's maximum size as partial replacement of natural coarse aggregate on the mechanical and durability properties of concrete. Resources, Conservation and Recycling v. 149, n. November 2018, p. 664$673,2019$.

GÜNEYISI, Erhan et al. Rheological and fresh properties of self-compacting concretes containing coarse and fine recycled concrete aggregates. Construction and Building Materials v. 113, p. 622-630 , 2016.0950-0618.

ISMAIL, Sallehan; HOE, Kwan Wai; RAMLI, Mahyuddin. Sustainable Aggregates: The 
Potential and Challenge for Natural Resources Conservation. Procedia - Social and Behavioral Sciences v. 101, p. 100-109 , 2013. Disponível em: <http://dx.doi.org/10.1016/j.sbspro.2013.07.183>.0000000000.

JAYASURIYA, Anuruddha et al. Development and statistical database analysis of hardened concrete properties made with recycled concrete aggregates. Resources, Conservation and Recycling v. 164, n. April 2020, p. 105121 , 2021. Disponível em: <https://doi.org/10.1016/j.resconrec.2020.105121>.

KHATIB, J. M. Properties of concrete incorporating fine recycled aggregate. Cement and Concrete Research v. 35, n. 4, p. 763-769, 2005.

KURDA, Rawaz; DE BRITO, Jorge; SILVESTRE, José D. Influence of recycled aggregates and high contents of fly ash on concrete fresh properties. Cement and Concrete Composites v. 84, p. 198-213, 1 nov. 2017.

LI, Xuping. Recycling and reuse of waste concrete in China. Part I. Material behaviour of recycled aggregate concrete. Resources, Conservation and Recycling v. 53, n. 1-2, p. $36-44,2008$.

MARINKOVIC, Snezana B. et al. Recycled Aggregate Concrete for Structural Use - An Overview of Technologies, Properties and Applications. In: FARDIS, Michael N. (Org.). . Innovative Materials and Techniques in Concrete Construction. Dordrecht: Springer Netherlands, 2012. Disponível em: <http://link.springer.com/10.1007/978-94007-1997-2>. 978-94-007-1996-5.

MENDES, Fernando Cruz. Sinal de alerta para a mineração de agregados em São Paulo: Precisamos planejar e atualizar as leis - A importância do ordenamento territorial. Areia e Brita n. 57, p. 24-28, 2012.

MUKHARJEE, Bibhuti Bhusan; BARAI, Sudhirkumar V. Influence of Nano-Silica on the properties of recycled aggregate concrete. Construction and Building Materials v. 55, p. 29-37 $\quad 2014 . \quad$ Disponível em: <http://dx.doi.org/10.1016/j.conbuildmat.2014.01.003>.

OMARY, Safiullah; GHORBEL, Elhem; WARDEH, George. Relationships between recycled concrete aggregates characteristics and recycled aggregates concretes properties. 
Construction and Building Materials v. 108, p. 163-174, 2016. Disponível em: <http://dx.doi.org/10.1016/j.conbuildmat.2016.01.042>.0950-0618.

PARK, Jinyoung et al. Accelerated carbonation of recycled aggregates using the pressurized supercritical carbon dioxide sparging process. Minerals v. 10, n. 6, 2020.

PÉREZ-BENEDICTO, J. A. et al. Características mecánicas de hormigones con áridos reciclados procedentes de los rechazos en prefabricación. Materiales de Construcción v. 62, n. 305, p. $25-37,2012$.

POON, C. S.; KOU, S. C.; LAM, L. Influence of recycled aggregate on slump and bleeding of fresh concrete. Materials and Structures/Materiaux et Constructions v. 40, n. 9, p. 981-988, 2007.

PRADO, Adelson Gomes Do. Assessing petrographic and experimental of coarse aggregates affects by tectonics deformation, minerals of alteration development and exsolution textures. Federal University of Pernambuco, 2008. 101 p.

RAHAL, Khaldoun. Mechanical properties of concrete with recycled coarse aggregate. Building and Environment v. 42, n. 1, p. 407-415, 2007.

RAO, Akash; JHA, Kumar N.; MISRA, Sudhir. Use of aggregates from recycled construction and demolition waste in concrete. Resources, Conservation and Recycling v. 50, n. 1, p. 71-81, 2007.

SALESA, Ángel et al. Physico - mechanical properties of multi-recycled concrete from precast concrete industry. Journal of Cleaner Production v. 141, p. 248-255 , 2017.

SANTOS, Sara A.; DA SILVA, Pedro R.; DE BRITO, Jorge. Mechanical performance evaluation of self-compacting concrete with fine and coarse recycled aggregates from the precast industry. Materials v. 10, n. 8, 2017.

SARAVANAKUMAR, P.; ABHIRAM, K.; MANOJ, B. Properties of treated recycled aggregates and its influence on concrete strength characteristics. Construction and Building Materials v. 111, p. 611-617, 2016. Disponível em: <http://dx.doi.org/10.1016/j.conbuildmat.2016.02.064>.09500618.

SHAO, Yixin et al. Accelerated Carbonation of Portland Limestone Cement. Journal of 
Materials in Civil Engineering v. 26, n. 1, p. 117-124, 2014.

SHI, Caijun et al. Performance enhancement of recycled concrete aggregate - A review. Journal of Cleaner Production v. 112, p. 466-472, 2016. Disponível em: <http://dx.doi.org/10.1016/j.jclepro.2015.08.057>.

SILVA, Rui Vasco; DE BRITO, Jorge; DHIR, Ravindra Kumar. Establishing a relationship between modulus of elasticity and compressive strength of recycled aggregate concrete. Journal of Cleaner Production v. 112, p. 2171-2186 , 2016. Disponível em: <http://dx.doi.org/10.1016/j.jclepro.2015.10.064>.0959-6526.

SILVA, R. V.; DE BRITO, J.; DHIR, R. K. Properties and composition of recycled aggregates from construction and demolition waste suitable for concrete production. Construction and Building Materials v. 65, p. 201-217 , 2014. Disponível em: <http://dx.doi.org/10.1016/j.conbuildmat.2014.04.117>.

SOARES, D. et al. Use of coarse recycled aggregates from precast concrete rejects: Mechanical and durability performance. Construction and Building Materials v. 71, p. 263-272 , 2014. Disponível em: 〈http://dx.doi.org/10.1016/j.conbuildmat.2014.08.034>.

TAFFESE, Woubishet Zewdu. Suitability Investigation of Recycled Concrete Aggregates for Concrete Production: An Experimental Case Study. Advances in Civil Engineering v. $2018,2018$.

The cement sustainability initiative, World Business Council for Sustainable Development. The Cement Sustainability Initiative (CSI). [S.l: s.n.]. Disponível em: <https://www.wbcsdcement.org/>. , 2009

UEPG, “(European Aggregates Association) - Estimates of aggregates production data," 2018. [Online]. Available: http://www.uepg.eu/statistics/estimates-of-production-data. [Accessed 19 August 2018]. . [S.1: s.n.]. , [S.d.]

WANG, Ruijun; YU, Ningning; LI, Yang. Methods for improving the microstructure of recycled concrete aggregate: A review. Construction and Building Materials v. 242, p. 118164 , 2020. Disponível em: <https://doi.org/10.1016/j.conbuildmat.2020.118164>.

XIAO, Jianzhuang; LI, Jiabin; ZHANG, Ch. Mechanical properties of recycled aggregate 
concrete under uniaxial loading. Cement and Concrete Research v. 35, n. 6, p. 1187$1194,2005$.

YANG, Keun Hyeok; CHUNG, Heon Soo; ASHOUR, Ashraf F. Influence of type and replacement level of recycled aggregates on concrete properties. ACI Materials Journal v. 105, n. 3, p. 289-296, 2008.

Recebido em: 12/09/2021

Aprovado em: 05/10/2021

Publicado em: 10/10/2021 